University of California, Hastings College of the Law UC Hastings Scholarship Repository

Faculty Scholarship

1999

\title{
On the Received Wisdom in Federal Courts
}

Evan Tsen Lee

UC Hastings College of the Law, leee@uchastings.edu

Follow this and additional works at: http://repository.uchastings.edu/faculty_scholarship

Part of the Courts Commons

\section{Recommended Citation}

Evan Tsen Lee, On the Received Wisdom in Federal Courts, 147 U. Pa. L. Rev. 1111 (1999).

Available at: http://repository.uchastings.edu/faculty_scholarship/350

This Article is brought to you for free and open access by UC Hastings Scholarship Repository. It has been accepted for inclusion in Faculty Scholarship by an authorized administrator of UC Hastings Scholarship Repository. For more information, please contact marcusc@uchastings.edu. 


\section{Faculty Publications \\ UC Hastings College of the Law Library}

Author: Evan Tsen Lee

Source: $\quad$ University of Pennsylvania Law Review

Citation: $\quad 147$ U. Pa. L. Rev. 1111 (1999).

Title: $\quad$ On the Received Wisdom in Federal Courts

Originally published in UNIVERSITY OF PENNSYLVANIA LAW REVIEW. This article is reprinted with permission from UNIVERSITY OF PENNSYLVANIA LAW REVIEW and University of Pennsylvania Law School. 


\section{ARTICLE}

\section{ON THE RECEIVED WISDOM IN FEDERAL COURTS}

\section{EVAN TSEN LEE $†$}

The received wisdom in federal courts law is that the United States Supreme Court should actively preserve the state courts as an important forum for the adjudication of federal constitutional claims. ${ }^{1}$ According to this wisdom, the Court must actively maintain a balance in the allocation of constitutional litigation between state and federal courts. Left on their own, many federal constitutional claimants would elect litigation or relitigation in a federal forum. The delicate balance between state and federal courts would be upset. Informed by this wisdom, the Court has built several important doctrinal walls around federal courts, including the rules barring federal courts from enjoining parallel actions in state courts, ${ }^{2}$ the rule according state court judgments preclusive effect in federal courts deciding civil rights claims, ${ }^{3}$ and the increasingly restrictive doctrines of federal habeas corpus. ${ }^{4}$

$\uparrow$ Professor of Law, University of Califomia, Hastings College of Law. Thanks to Larry Alexander, Vik Amar, Ash Bhagwat, Kate Bloch, Don Doemberg, David Faigman, Barry Friedman, Reuel Schiller, Michael Wells, and Chris Wonnell for helpful comments on early drafts. Thanks also to Corie Edwards and Dipanwita Deb Amar for their outstanding research assistance. I gratefully acknowledge receipt of the Roger Traynor Scholarly Publication Award in conjucntion with this work.

1 See infra notes 36-45 and accompanying text (citing cases and law review articles that explicate and exemplify this view).

${ }^{2}$ See Younger v. Harris, 401 U.S. 37, 54 (1971) (holding that a federal court may not enjoin an existing criminal prosecution in state court in the absence of bad faith or harassment); see also Hicks v. Miranda, 422 U.S. 332, 348-49 (1975) (extending Younger to cases in which the state prosecution was filed after the federal action, but before any proceedings of substance on the merits had taken place in federal court); Huffman v. Pursue, Ltd., 420 U.S. 592, 611-12 (1975) (extending Younger to some cases in which the state proceeding is civil rather than criminal); Atlantic Coast Line R.R. v. Brotherhood of Locomotive Eng'rs, 398 U.S. 281, 296-97 (1970) (holding that it was improper for the federal district court to enjoin the enforcement of an injunction issued by a state court).

3 See Allen v. McCurry, 449 U.S. 90, 105 (1980) (applying collateral estoppel to bind the federal courts to a state court judgment for a civil rights plaintiff).

${ }^{4}$ See, e.g., Rose v. Lundy, 455 U.S. 509, 522 (1982) (requiring a federal district court to dismiss a habeas petition containing exhausted and unexhausted state claims); Wainwright $v$. Sykes, 433 U.S. 72, 90-91 (1977) (barring federal habeas corpus review of a constitutional claim absent a showing of "cause" and "prejudice" where a timely objection was not made during the state court proceeding); Stone v. Powell, 428 U.S. 465, 494-95 (1976) (holding that 
The commitment to channel constitutional litigation into state court has even prompted the Court to read the vast majority of procedural due process claims out of the Constitution, leaving them outside federal cognizance. ${ }^{5}$ Although some decisions of the Warren Court appeared to break with the received wisdom, permitting many litigants to opt for litigation or relitigation of their federal constitutional claims in federal court, ${ }^{6}$ it is now clear that the Warren Court only temporarily interrupted the ancien regime. The Burger and Rehnquist Courts have renewed the traditional commitment to maintaining a quantitative and qualitative balance between state and federal courts as arbiters of federal constitutional claims. ${ }^{7}$

A variety of reasons have been invoked to support this program of maintaining balance. One is positive law. In each of the above-mentioned doctrinal areas, there are at least a few hoary cases supporting restrictions on access to federal court. ${ }^{8}$ Another reason is historical. Article III of the

exclusionary rule claims are not cognizable during federal habeas corpus review unless the state court has denied a full and fair hearing).

${ }^{5}$ See Daniels v. Williams, 474 U.S. 327, 335 (1986) (holding that a state official's negligence does not violate the Due Process Clause); Parratt v. Taylor, 451 U.S. 527, 533-34 (1981) (finding that negligent deprivations of property do not violate the Due Process Clause where the state provides an adequate post-deprivation remedy), overruled on other grounds by Daniels, 474 U.S. at 330-31; see also Hudson v. Palmer, 468 U.S. 517, 533 (1984) (extending Parratt v. Taylor to intentional deprivations of property).

${ }^{6}$ See, e.g., Dombrowski v. Pfister, 380 U.S. 479, $497-98$ (1965) (permitting an action in federal court to enjoin a state prosecution under an allegedly overbroad criminal statute); Fay v. Noia, 372 U.S. 391, 438 (1963) (asserting that federal habeas courts will review a procedurally defaulted claim unless the petitioner "deliberately by-passed" it in state court), overruled in part by Wainwright, 433 U.S. at 87-91; Monroe v. Pape, 365 U.S. 167, 172, 183 (1961) (holding that one whose constitutional rights have been violated by a state official may sue in federal court under what is now 42 U.S.C. $\$ 1983$ even when state law provides a remedy), overruled on other grounds by Monell v. Department of Soc. Servs., 436 U.S. 658 (1978).

${ }^{7}$ See supra notes 2-5 and accompanying text (discussing doctrines designed to protect this balance).

8 The Court in Parratt could cite two cases upholding governmental deprivations of property without a predeprivation hearing. See Bowles v. Willingham, 321 U.S. 503, 521 (1944) (holding that preliminary hearings are not required where "Congress has provided for judicial review after the regulations or orders have been made effective [because] it has done all that due process ... requires"); North Am. Cold Storage Co. v. City of Chicago, 211 U.S. 306,313 (1908) (concluding that a municipal order adopted under powers granted by the state legislature should be regarded as an act of the state). The opinion in Younger could claim support from Fenner v. Boykin, 271 U.S. 240, 243-44 (1926), allowing federal courts to enjoin state officers from instituting criminal prosecutions only "where the danger of irreparable loss is both great and immediate," and its progeny. See Douglas v. City of Jeannette, 319 U.S. 157, 163-64 (1943) (ruling that federal courts should not interfere with state criminal proceedings unless there are exceptional circumstances and a clear showing of imminent irreparable loss); Williams v. Miller, 317 U.S. 599, 599 (1942) (same); Watson v. Buck, 313 U.S. 387, 401 (1941) (same); Beal v. Missouri Pac. R.R., 312 U.S. 45, $50-51$ (1941) (same); Spielman Motor Sales Co. v. Dodge, 295 U.S. 89, 95 (1935) (holding that a challenge to the 
Constitution does not itself require the creation of lower federal courts. ${ }^{9}$ Therefore, the thinking goes, the Framers must have believed that state courts would be the arbiters of most federal constitutional claims. ${ }^{10}$ Still another reason is practical. There exists a widespread belief that the federal courts are overloaded with cases. ${ }^{11}$ Shunting many federal claims to the state courts helps relieve this congestion. A final reason to maintain a balance in the allocation of federal constitutional claims between state and federal courts grows out of normative political philosophy. Nurturing the strength and sovereignty of state judicial systems is considered a good thing because strong state courts can act as a powerful brake on an overreaching federal government or federal judiciary. State court practice in federal constitutional litigation must be kept strong so that state courts will be there to protect individual freedom when all else fails. ${ }^{12}$ Moreover, state court practice provides the nation with "fifty laboratories" that might give birth to new ideas or procedures promoting the cause of liberty. ${ }^{13}$

In this Article, I do not address the legal, historical, or practical arguments that might support the Supreme Court's program of balancing the allocation of constitutional cases between state and federal courts. Other

validity of a state statute should be brought in state court unless there are "exceptional circumstances and a clear showing that an injunction is necessary in order to afford adequate protection of constitutional rights"). But see Douglas Laycock, Federal Interference with State Prosecutions: The Cases Dombrowski Forgot, 46 U. CHI. L. REv. 636, 644-45, 656 (1979) (asserting that none of the above cases squarely holds relief unavailable as to future rather than past conduct).

9 Article III, Section 1 of the Constitution states in pertinent part: "The judicial Power of the United States, shall be vested in one supreme Court, and in such inferior Courts as the Congress may from time to time ordain and establish." U.S. CONST. art. III, $\S 1$. This sentence was the product of the so-called "Madisonian Compromise," wherein a bloc of delegates supporting the self-executing creation of lower federal courts and a bloc of delegates opposing even the possibility of such courts were induced to accept a provision leaving the matter to Congress, For a recent look at the Madisonian Compromise, see Michael G. Collins, Article III Cases, State Court Duties, and the Madisonian Compromise, 1995 WIS. L. REV. 39, 11619.

10 This way of thinking underlies Sheldon v. Sill, 49 U.S. (8 How.) 440, 448-49 (1850), holding that the Judiciary Act of 1789 defines the scope of lower federal court jurisdiction, even where it seemingly contradicts Article III power.

11 See, e.g., FEDERAL COURTS STUDY COMMISSION, REPORT OF THE FEDERAI COURTS STUDY COMM. 4-10, 35-38 (1990) (discussing "the federal courts' caseload crisis").

12 See infra notes 33-39 and accompanying text (discussing the need to preserve state courts as a forum for constitutional litigation).

${ }^{13}$ See New State Ice Co. v. Liebmann, 285 U.S. 262, 311 (1932) (Brandeis, J., dissenting) (claiming that a virtue of the federal system is that "a single courageous State may, if its citizens choose, serve as a laboratory; and try novel social and economic experiments without risk to the rest of the country"). 
scholars have thoroughly analyzed those issues elsewhere. ${ }^{14}$ Rather, I wish to examine the normative political philosophy that underlies the received wisdom. Are the defenders of the received wisdom on solid ground when they say that maintaining this balance between state and federal courts promotes the cause of individual liberty in America? Should we really take comfort in the knowledge that state judicial systems are innovating new ideas and procedures that may lead to greater individual freedom from government oppression? Many, if not most, judges and scholars seem to assume that the answers to these questions are unproblematically affirma-

14 Many scholarls have examined whether the text and history of Article III require Congress to vest federal courts with federal question jurisdiction. See JULIUS GOEBEL, JR., HISTORY OF THE SUPREME COURT OF THE UNITED STATES: ANTECEDENTS AND BEGINNINGS TO 1801, at 246-47 (1971) (arguing that under Article III Congress must create lower federal courts and vest them with full Article III jurisdiction); Akhil Reed Amar, A NeoFederalist View of Article III: Separating the Two Tiers of Federal Jurisdiction, 65 B.U. L. REV. 205, 209 (1985) [hereinafter Amar, A Neo-Federalist View] (asserting that Article III requires that some federal court be available to hear cases arising under federal law, affecting ambassadors, and in admiralty); Akhil Reed Amar, Reports of My Death are Greatly Exaggerated: A Reply, 138 U. PA. L. REV. 1651 (1990) (responding to Meltzer and other critics); Paul M. Bator, Congressional Power over the Jurisdiction of the Federal Courts, 27 VILL. L. REV. 1030, 1038, 1040 (1982) (calling for broad congressional discretion); William R. Casto, The First Congress's Understanding of Its Authority over the Federal Courts' Jurisdiction, 26 B.C. L. REV. 1101, 1102 (1985) (criticizing Clinton's thesis as "inconsistent with the enactment of the Judiciary Act of 1789'); Robert N. Clinton, A Mandatory View of Federal Court Jurisdiction: A Guided Quest for the Original Understanding of Article III, 132 U. PA. L. REV. 741, 750 (1984) (asserting that the Constitution does not give Congress "a license to curtail" the exercise of the judicial power); Theodore Eisenberg, Congressional Authority to Restrict Lower Federal Court Jurisdiction, 83 YALE L.J. 498, 501 (1974) (arguing that "the premise that Congress may abolish the lower federal courts is false"); Daniel J. Meltzer, The History and Structure of Article III, 138 U. PA. L. REV. 1569, 1569 (1990) (criticizing Amar's view "that Congress has plenary authority over federal court jurisdiction"); Martin H. Redish, Constitutional Limitations on Congressional Power to Control Federal Jurisdiction: A Reaction to Professor Sager, 77 Nw. U. L. REV. 143, 144 (1982) (refuting Sager's assertions 'that there always be at least one Article III forum to review assertions of constitutional right, [and] that "selective deprivations" by Congress of federal jurisdiction to review [those] assertion[s] ... are unconstitutional"); Lawrence Gene Sager, The Supreme Court, 1980 TermForeword: Constitutional Limitations on Congress' Authority to Regulate the Jurisdiction of the Federal Courts, 95 HARV. L. REV. 17 (1981) (arguing that the Constitution requires either original or appellate federal jurisdiction of constitutional claims).

For views on the practical consequences of channeling federal claims to state courts, see Burt Neuborne, The Myth of Parity, 90 HARV. L. REV. 1105 (1977), suggesting that federal courts are more sympathetic to federal claims; Michael E. Solimine \& James L. Walker, Constitutional Litigation in Federal and State Courts: An Empirical Analysis of Judicial Parity, 10 HASTINGS CONST. L.Q. 213, 246-53 (1983), concluding that state courts are as likely to rule in favor of constitutional claims as are federal courts; and Erwin Chemerinsky, Parity Reconsidered: Defining a Role for the Federal Judiciary, 36 UCLA L. REV. 233, 261-69 (1988), critiquing Solimine \& Walker's methodology. 
tive. ${ }^{15}$ The purpose of this Article is to test the strength of those assumptions.

This Article proceeds in three parts. First, I briefly describe the social and political values upon which my analysis is based. Whether a particular idea or system is normatively attractive depends largely on the norms against which it is judged. My normative analysis is based on the assumption that, in the abstract, the preservation of individual liberty and dignity is accorded a privileged position relative to collective needs (such as social order, public health, material well-being, and protection of morals). Of course, I do not mean that every claim of individual right must prevail over any state interest. I simply mean that the playing field is tilted in favor of the individual, such that government is always fighting an uphill battle to justify incursions on individual freedom or dignity. Moreover, my analysis is based on the notion that evaluations of claims about individual freedom are to be viewed from the perspective of the individual, not from the standpoint of society. We may not validate a claim, for example, by pointing out that it gives very great freedom to a large number of people in society, while enslaving only a small number. Proposals to maximize individual freedom must be evaluated from the standpoint of those whose freedom fares worst under the proposal. I refer to this entire package of assumptions as the "individualist premise."

Part II of the Article offers a straightforward critique of the received wisdom. Here I argue that strengthening state constitutional practice is not a costless venture. By channeling constitutional claims to state courts, we endanger the rights of some individuals today so that we can better protect the rights of others in the future. This is the sort of gambit that ought to be disfavored, given our system of values. For precisely the same reason, we should be uncomfortable with the idea of shunting constitutional claims to state court for the purpose of having "fifty laboratories" develop rules that better protect individual liberty. ${ }^{17}$ I do not deny the possibility that individual freedom, in the aggregate, benefits from doctrinal innovations that grow out of constitutional litigation in the various state courts. It is, however, inconsistent with our values to experiment with the liberty of individual citizens. Providing the state courts with additional constitutional claims risks sacrificing individual liberty in some localities for the prospect of increasing individual liberty in other localities. The liberty of some is gambled with, in the hope of increasing the total amount of liberty of others in the system.

15 See infra notes 38-43 (citing judges and scholars who have argued that maintaining a balance of power between federal and state courts promotes liberty).

${ }^{16}$ See infra notes 18-20 and accompanying text (further elaborating this view).

17 I sometimes use "liberty" as shorthand for individual rights, including property rights. 
Part III of the Article attempts to make an affirmative case for the normative attractiveness of a system that generally guarantees federal constitutional claimants at least one full hearing in federal court. Such a system runs strongly counter to the received wisdom because it makes no provision for maintaining a balance of federal constitutional litigation between state and federal courts. If federal constitutional claimants were overwhelmingly to opt for litigation or relitigation of their claims in federal court, state court dockets might be emptied of certain types of constitutional cases. Moreover, many state court judgments could be effectively undone by federal court relitigation. Part III offers an argument for why we should nonetheless prefer such a system over the present system, at least from the standpoint of pure political philosophy. Legal, historical, and practical considerations may well make a system that guarantees one hearing in federal court impossible. If such a system is philosophically preferable to the received wisdom, however, then we may at least want to approximate that system as best we can.

It is important to note the structure of my argument. Parts II and III are logically dependent on the conclusions reached in Part I. That is, if one disagrees with the premises asserted in Part $I$, then the rest of this Article can have no persuasive force. Parts II and III, however, are logically severable from one another. One could agree with my negative critique of the received wisdom without acceding to my affirmative case for a system guaranteeing a plenary hearing in federal court. It is possible to conclude that the received wisdom is flawed, but that I have failed to make out a case for my chosen alternative.

\section{INDIVIDUAL RIGHTS AND COLLECTIVE NEED}

One of the most distinguishing features of a western liberal democracy is its solicitude for the individual. In the liberal state, individual citizens generally are not expected to make heroic sacrifices for an ultimate deity, the state-sponsored church, a dictator, the fatherland, the proletariat, or the greater good. The liberal state takes seriously its obligation to treat individuals as ends in themselves, rather than as means to greater ends. ${ }^{18}$ With its commitment to the protection of individual rights and individual autonomy, the liberal state necessarily rejects any full-blown version of utilitarianism. ${ }^{19}$ The liberal credo is anathema to the notion of maximizing utility

${ }^{18}$ See JOHN RAWLS, A THEORY OF JUSTICE 183 (1971) ("In the design of the social security system we must treat persons solely as ends and not in any way as means."). 
without regard for the separateness of individuals. Society is not just one huge, undifferentiated utility pool. Individual identity matters. ${ }^{20}$

What I have just described, of course, is more a caricature than a portrait of any existing society. Even the most liberal states regularly require individual citizens to sacrifice for the collective good. The progressive income tax appropriates property from wealthier individuals and redistributes it (through many intermediaries) to the less wealthy. Regulatory schemes limit individual freedom in the name of public safety or health, protection of the environment, proper functioning of the marketplace, and other community goals. It cannot be said that liberal states only ask for relatively trivial sacrifices from their citizens. In time of war, liberal states have in the past implemented, and doubtless will again in the future implement, forced conscription of soldiers to defend themselves. ${ }^{21}$ How many Americans paid the ultimate price for "the collective good" in Vietnam and Korea?

The difference between liberal states and authoritarian or fundamentalist states is ultimately one of degree. Still, an essential attribute of American political culture is that we believe our commitment to respect individual autonomy meaningfully distinguishes us from much of the world. We teach our children that it is better to let ten guilty people go free than to convict one innocent person. I doubt most Americans really feel this way; a more reasonable guess is that they would lose their patience around the third or fourth acquittal. But this hardly diminishes the power of the observation. Why should we prefer to free even two guilty people rather than convict one innocent person? Why do we not regard incorrect outcomes in the criminal justice system as fungible? It would not be irrational in the least to engineer the criminal justice apparatus to convict innocent people at roughly the same rate that guilty people are freed. It would be perfectly sane to think of this arrangement as optimal because it strikes a perfect balance between individual rights and social order. Amazingly, political morality has never supported any such proposition. ${ }^{22}$

19 See RONALD DWORKIN, TAKING RIGHTS SERIOUSLY at vii (1977) (discussing a liberal theory of law that champions individual rights as inconsistent with utilitarianism and legal positivism).

20 See RAWLS, supra note 18, at 22-24, 27, 181, 183, 187 (arguing that "classical utilitarianism fails to take seriously the distinction between persons" and tends to make people less confident of their personal worth); Bernard Williams, A Critique of Utilitarianism, in J.J.C. SMART \& BERNARD WILLIAMS, UTILITARIANISM, FOR AND AGAINST 77 (1973) (discussing the negative implications of utilitarianism).

21 See, e.g., United States v. O'Brien, 391 U.S. 367, 382 (1968) (upholding a conviction for buming of draft cards during the Vietnam War, pursuant to the Universal Military Training and Service Act of 1948, which was also in force during the Korean War).

${ }^{22}$ See Richard S. Bell, Decision Theory and Due Process: A Critique of the Supreme Court's Lawmaking for Burdens of Proof, 78 J. CRIM. L. \& CRMINOLOGY 557, 562 (1987) 
This skewing of the playing field in favor of the individual manifests itself most vividly in the criminal sphere. For example, the reasonable doubt standard, ${ }^{23}$ the probable cause and warrant requirements, ${ }^{24}$ and the privilege against self-incrimination, ${ }^{25}$ to name the most conspicuous, all favor individual rights. The tendency to favor individuals is prominent throughout much of American public law as well. Courts, not governmental functionaries, decide what constitutes "just compensation" for a taking. ${ }^{26}$ Courts are required to give the best practicable notice to individuals before adjudicating their rights, even when each individual has a relatively insignificant interest. ${ }^{27}$ Governments must provide due process before depriving individuals of life, liberty, or property. ${ }^{28}$

Each of the above-mentioned doctrines, both criminal and civil, is probably counter-utilitarian. Overall, social utility would likely increase without these rules because each one imposes significant transaction costs on government or judicial actions aimed at benefiting large numbers of people. The countervailing value in each case is fairness to the affected individual. Of course, any moderately clever utilitarian can always posit that each of these procedural rules creates some secondary type of utility-for example, one could argue that the just compensation rule stabilizes real estate markets, or that the Due Process Clause allows us to function day-today without being paralyzed with worry about arbitrary governmental action. But scenarios like these seem more fanciful than real. There is no particular reason to think that a private insurance market would not restore stability in real estate markets, or that market values would not simply change to reflect insecurity against the prospect of eminent domain. Even the absence of due process for government deprivations would probably only paralyze those who know themselves to be targets of the government or its officials.

(noting that the principle that it is better to let ten guilty people go free than to convict one innocent "is surely part of common political morality"). This principle is usually attributed to 4 WILLIAM BLACKSTONE, COMMENTARIES *358-59.

${ }^{23}$ See In re Winship, 397 U.S. 358, 364 (1970) (holding that "the Due Process Clause protects the accused against conviction except upon proof beyond a reasonable doubt of every fact necessary to constitute the crime with which he is charged").

24 See U.S. CONST. amend. IV.

${ }^{25}$ See U.S. CONST. amend. V.

${ }^{26}$ See Monongahela Navigation Co. v. United States, 148 U.S. 312, 327 (1893) ("[T]he question of compensation is judicial.").

${ }^{27}$ See, e.g., Mullane v. Central Hanover Bank \& Trust Co., 339 U.S. 306, 314-15 (1950) (concluding that trustees of a common fund were required to give notice "reasonably calculated" to reach known beneficiaries, even though many of the beneficiaries held only small interests in the fund).

${ }^{28}$ See U.S. CONST. amend XIV. 
How did American legal and political culture come to this commitment to individualism? Different generations of historians have different answers. During the 1950s, historians argued either that individualism entered American political culture because of the Enlightenment, or that it originated from the unique circumstances surrounding the colonization of North America (such as plentiful land and absence of nobility). ${ }^{29}$ During the 1960 s and 1970s, some historians developed a more materialistic explanation for the development of individualism in the United States. They argued that individualist ideology was a product of capitalism. ${ }^{30}$ Elites favored an ideology that eliminated feudal paternalism and replaced it with a belief system that minimized government restrictions on individual economic activity. ${ }^{31}$ The present generation of historians may be headed toward other explanations. William Novak argues that individualist ideology is a reaction to the post-Civil War centralization of administrative and political power. $^{32}$ Thus, historians cannot agree on how America embraced the individualist credo. But not even the historians most closely associated with republicanism deny the historical triumph of liberal individualism in the United States. ${ }^{33}$

Whatever the history, this Article takes the general elevation of individual rights over collective need as its point of departure. In arguing about what makes up the most normatively attractive distribution of constitutional

${ }^{29}$ See DANIEl J. BOORSTIN, THE GeNIUS OF AMERICAN POLITICS 61-65 (1953) (arguing that early Puritans influenced American political theory and morality); LOUIS HARTZ, THE LIBERAL TRADITION IN AMERICA 9 (1955) (suggesting that the lack of feudalism contributed to a unique American liberalism).

${ }^{30}$ See Elizabeth FoX-Genovese \& Eugene D. Genovese, Frutts of MERChaNT CAPITAL 267-98 (1983) (exploring the rise of capitalism and its influence on an ideology of individualism); MORTON J. HORWTTZ, THE TRANSFORMATION OF AMERICAN LAW, 17801860 , at 109-39 (1977) (discussing the growth of business competition and its influence on American society).

${ }^{31}$ See WILLIAM APPLEMAN WILLIAMS, THE CONTOURS OF AMERICAN HISTORY 53-65 (1961) (charting the move from the feudalism of Anthony Ashley Cooper, First Earl of Shaftesbury, to the individualism of John Locke).

${ }^{32}$ See WILliam J. NOVAK, THE PEOPLE's Welfare: LAW AND REgulation IN NINETEENTH-CENTURY AMERICA 240-41 (1996) (discussing the relationship between "centralization of power" and "individualization of subjects [in] postbellum America"). For a review of Novak's book, see Reuel E. Schiller, Regulation's Hidden History, 25 REV. AM. HIST. 416, 416-21 (1997).

${ }^{33}$ See, e.g., BERNARD BAILYN, THE IDEOLOGICAL ORIGINS OF THE AMERICAN REVOLUTION 55 (1967) (describing Americans' rejection of English "tyranny" and corruption in favor of "vindicating their liberties and just rights"); GORDON WOOD, THE CREATION OF THE AMERICAN REPUBLIC, 1776-1787, at 46-90 (1969) (discussing the growth of republicanism and its conception of equality and individual rights in government). For an explanation of how liberalism triumphed in the framing of the Just Compensation Clause, see William Michael Treanor, The Origins and Original Significance of the Just Compensation Clause of the Fifth Amendment, 94 YALE L.J. 694 (1985). 
claims between state and federal courts, I cannot deviate from the individualist premises of a western liberal democracy. I am aware of the rich literature both within and without the legal academy concerning various forms of liberalism and communitarianism. ${ }^{34}$ Perhaps it is true that Americans have a tragically impoverished conception of the community, and that society is rightfully entitled to claim much more from the individual than it presently does. As a matter of first principles, these claims are hardly insubstantial. This is not, however, the appropriate place to visit such a discussion.

\section{THE INDIVIDUALIST CRITIQUE OF THE RECEIVED WISDOM}

I have described the "received wisdom" in federal courts law as a belief that the Supreme Court should actively preserve the state courts as an important forum for the adjudication of federal constitutional claims. ${ }^{35}$ Although some embrace this belief because of their interpretations of the Framers' original intent, and others may come to this conclusion because of fears about the congestion of federal court dockets, the Court itself, at least in part, embraces it as a matter of political philosophy. Consider Younger $v$.

34 Liberals generally divide into two subgroups-libertarians and egalitarian liberals. Both groups are devout in their commitments to individual liberty but divide on issues of distributive justice. The best example of a strong libertarian position is found in ROBERT NOZICK, ANARCHY, STATE, AND UTOPIA (1974). The best examples of egalitarian liberalism are found in JOHN RAWLS, A THEORY OF JUSTICE (1971); Ronald Dworkin, What is Equality? Part 1: Equality of Welfare, 10 PHIL. \& PUB. AFF. 185 (1981); and Ronald Dworkin, What is Equality? Part 2: Equality of Resources, 10 PHL. \& PUB. AFF. 283 (1981). For more general treatments of liberalism, see RONALD DWORKN, Liberalism, in A MATIER OF PRINCIPLE 181 (1985); ISAIAH BERLIN, Two Concepts of Liberty, in FOUR ESSAYS ON LIBERTY 118-72 (1969); and Jeremy Waldron, Theoretical Foundations of Liberalism, 37 PHIL. Q. 127 (1987). Though few scholars consciously identify themselves as "communitarians," many are critical of an atomistic social structure. A fairly full conception of communitarianism is laid down in MICHAEL J. SANDEL, LIBERALISM AND THE LIMITS OF JUSTICE 14754 (1982). Many communitarians have rallied around the Aristotelian approach set forth in AlASDAIR MACINTYRE, AFTER VIRTUE: A STUDY IN MORAL THEORY (2d ed. 1984). Some associate the "civic republican" movement among legal scholars with communitarianism. See, e.g., Frank Michelman, Law's Republic, 97 YALE L.J. 1493, 1495 (1988) (arguing that republican constitutional thought is tied to political communities); Suzanna Sherry, Civic Virtue and the Feminine Voice in Constitutional Adjudication, 72 VA. L. REV. 543, 546-50 (1986) (describing the classical paradigm of political philosophy as community-oriented and associating this paradigm with classical republicanism); Cass R. Sunstein, Beyond the Republican Revival, 97 YALE L.J. 1539, 1576-90 (1988) (exploring the "republican revival" and its influence on the American political process). For a recent argument that the chasm between "republicanism" and "liberalism" has been overdrawn, see Mortimer Sellers, Republicanism, Liberalism, and the Law, 86 KY. L.J. 1 (1997-98).

${ }^{35}$ See supra text accompanying notes 1-12 (discussing the federal courts' "received wisdom"). 
Harris, ${ }^{36}$ a case in which the Court held that individuals prosecuted under a state antisubversives criminal statute could not invoke federal court jurisdiction to challenge the unconstitutionality of the law. Justice Black wrote:

This underlying reason for restraining courts of equity from interfering with criminal prosecutions is reinforced by an even more vital consideration, the notion of "comity," that is, a proper respect for state functions, a recognition of the fact that the entire country is made up of a Union of separate state governments, and a continuance of the belief that the National Government will fare best if the States and their institutions are left free to perform their separate functions in their separate ways. ${ }^{37}$

From her days as a state court appellate judge, Justice O'Connor has echoed the notion that the Supreme Court must take steps to preserve state courts as a high quality forum for constitutional litigation:

[W]e should strive to make both the federal and the state systems strong, independent, and viable.... If we are serious about strengthening our state courts and improving their capacity to deal with federal constitutional issues, then we will not allow a race to the courthouse to determine whether an action will be heard first in the federal or state court. We should allow the state courts to rule first on the constitutionality of state statutes. ${ }^{38}$

Justice Robert Sheran argues that the omnipresent threat of Congress selectively stripping federal court jurisdiction provides another reason to preserve the state courts as forums for constitutional claims:

The national interest in improving the administration of justice in state court systems as possible forums for the protection of rights secured by the Federal Constitution and federal laws should be acknowledged, particularly in light of the fact that the Congress can and someday may limit the jurisdiction of federal district courts in dealing with matters of this kind. ${ }^{39}$

The late Professor Paul Bator gave the fullest elaboration of this thinking. He began with the premise that state courts will inevitably play a substantial role in the formulation and application of federal constitutional rules. "If this is so," Bator wrote, "we must try to create conditions to assure optimal performance by the state courts. ${ }^{, 40}$ The creation of such con-

${ }^{36} 401$ U.S. 37 (1971).

37 Id. at 44.

38 Sandra D. O'Connor, Trends in the Relationship Between the Federal and State Courts from the Perspective of a State Court Judge, 22 WM. \& MARY L. REV. 801, 814-15 (1981).

39 Robert J. Sheran, State Courts and Federalism in the 1980's: Comment, 22 WM. \& MARY L. REV. 789, 800 (1981).

${ }^{40}$ Paul M. Bator, The State Courts and Federal Constitutional Litigation, 22 WM. \& MARY L. REV. 605, 624 (1981). 
ditions depends upon state judges embracing federal constitutional law as their own. How, Bator asked, can such an attitude be fostered?

\begin{abstract}
Competence and sensitivity are themselves not static phenomena. Conscientiousness, dedication, idealism, openness, enthusiasm, willingness to listen and to learn-all the mysterious components of the subtle art of judging well-are at least to some extent best evoked by a sense of responsibility, by the realization that one has been entrusted with a great and important task. I can think of nothing more subversive to the judge's inner sense of responsibility than the notion that, to the greatest possible extent, all the important shots will be called by someone else because we don't believe in his or her competence and sensitivity. If we want the state judges to internalize the sense that they, too, speak for the Constitution-that it is their Constitution-we must not too easily construct our jurisdictional and remedial rules on the premise that they can't and won't speak for the Constitution. If we want state judges to feel institutional responsibility for vindicating federal rights, it is counterproductive to be grudging in giving them the opportunity to do so. ${ }^{41}$
\end{abstract}

The doctrinal solution, Bator argued, was to allow state courts to dispositively adjudicate cases so long as federal constitutional claimants were given a "full and fair opportunity" to litigate the constitutional question in the state tribunal. ${ }^{42}$ Bator had originally suggested this formulation in 1963. ${ }^{43}$ The Supreme Court's immediate reaction was to reject this solution, ${ }^{44}$ but the Court later reversed itself and adopted it in more than one doctrinal context. ${ }^{45}$ Bator's "full and fair opportunity" solution, of course, constitutes one articulation of the "received wisdom" as I have described it.

41 Id. at 624-25. An important contemporary federal courts scholar has further developed this line of Bator's thinking. See Ann Althouse, How to Build a Separate Sphere: Federal Courts and State Power, 100 HARV. L. REV. 1485, 1489 (1987) (arguing that "the federal interest in the states as effectively functioning entities includes both having states follow and apply federal law in their courts and encouraging states to develop their own law governing their own institutions").

${ }^{42}$ Bator, supra note 40 , at 626.

43 See Paul M. Bator, Finality in Criminal Law and Federal Habeas Corpus for State Prisoners, 76 HARV. L. REV. 441, 527-28 (1963) (concluding that "where a federal constitutional question has been fully canvassed by fair state process, and meaningfully submitted for possible Supreme Court review, then the federal district judge on habeas ... has a large discretion to decide whether the federal error, if any, was prejudicial").

[T] he availability of the ... Writ of habeas corpus in the federal courts for persons in the custody of the States offends no legitimate state interest in the enforcement of criminal justice or procedure.... If the States withhold effective remedy, the federal courts have the power and the duty to provide it.

Fay v. Noia, 372 U.S. 391, 440-41 (1963), overruled in part by Wainwright v. Sykes, 433 U.S. 72 (1977).

${ }^{45}$ See Allen v. McCurry, 449 U.S. 90, 103-05 (1980) (holding that state court decisions have preclusive effect on federal courts deciding claims under 42 U.S.C $\$ 1983$ (1994)); Stone v. Powell, 428 U.S. 465, 494-95 (1976) (holding that exclusionary rule claims are not cogni- 
The above-quoted statements drive at the same basic idea-that state courts must always have a steady and substantial flow of federal constitutional claims, so as to improve their ability to handle such claims. Of course, this assertion rests on the empirical supposition that "practice makes perfect." It assumes that the quality of state court constitutional adjudication will improve if the quantity increases. It also assumes that such adjudication will improve if the level of federal court second-guessing decreases. These are controversial assumptions. Is a bigoted state judge really more likely to uphold the equal protection rights of black people if we give him many such cases instead of a few? Is the situation likely to improve if we make sure he knows there will be no federal judges looking over his shoulder as long as he provides a "full and fair" 46 opportunity to litigate the constitutional claims? The answers to these questions are not obviously affirmative.

I wish to make it clear, however, that my critique does not rest on this empirical challenge. I assume for the sake of argument that state judges who presently are inclined to give federal constitutional claims short shrift will eventually become more favorably disposed to them if they are given more of them. I wish to assume that state judges who presently do a substandard job with federal constitutional claims because of unfamiliarity with them will eventually acquire greater proficiency. I wish to assume that state judges who presently do not embrace federal constitutional law as their own will eventually feel a.more proprietary interest in it if they are subjected to less federal review.

How does the received wisdom now fare against the backdrop of our individualistic values? It still fails. It sacrifices present-day constitutional claimants in favor of future claimants. More accurately, the received wisdom exposes a relatively small number of present-day claimants to a higher probability of erroneous decisions in order to reduce the exposure of a larger number of future claimants to such treatment. ${ }^{47}$

From the standpoint of the individual, this is highly suspect. The received wisdom would sacrifice the quality of process for one group of individuals in order to increase the quality of process for another group. People whose constitutional claims normally would have been heard in federal

zable on federal habeas review if the state court provided "full and fair" opportunity to litigate); Younger v. Harris, 401 U.S. 37, 54 (1971) (holding that federal courts may not enjoin pending state criminal prosecution absent "an "unusual circumstance that would call for equitable relief').

${ }^{46}$ Stone v. Powell, 428 U.S. at 494.

47 This idea makes utilitarian sense, whereas my original statement ("it sacrifices presentday claimants in favor of future claimants") is a utilitarian wash. 
court will be shunted to state court, where they are less likely to receive high-quality adjudication. Over time, the increased flow of such claims to state court will improve the quality of such adjudication. Eventually, everybody will receive high-quality adjudication, whether in federal or state court. Earlier claimants are thus martyred on the mantle of judicial pedagogy.

This kind of interpersonal utility exchange is greatly disfavored in western liberal democracies. At its most extreme, such thinking could potentially sanction the harvesting of the organs of a few for the benefit of many deserving recipients. Such thinking could purport to justify the enslavement of a few for the benefit of many. I will readily concede that these are the ugliest in the parade of horribles; no one really thinks anything we do with jurisdictional rules is going to lead to organ harvesting or slavery. But I stand by the central point of the illustrations: exacting sacrifices from one group to benefit others is presumptively undesirable. It should make our teeth gnash.

Three objections to my argument surely will be made. First, some will object to my assumption that present state court constitutional adjudication is substandard. If this assumption is incorrect, then no one is forced to sacrifice anything. Second, some will point out that western liberal democracies constantly force these kinds of individual sacrifices for the larger good of society. Third, some will argue that there is nothing wrong with sacrificing present-day constitutional claimants because they have no right to be in federal court in the first place. I will address these objections in turn.

\section{A. May We Assume State Court Adjudication Is Substandard?}

The first objection to my critique of the received wisdom is that I am incorrect when I assume that state court constitutional adjudication is inferior to federal court constitutional adjudication. In fact, according to this objection, state courts are the equals of federal courts in handling constitutional litigation. Therefore, forcing constitutional claimants to litigate in state court does not hurt them in any way. The individualist premise of western liberal democracy is not violated or even strained.

Academics have engaged in an unending debate over the posited equality of state and federal courts in the handling of constitutional claims. Some argue that life tenure and salary protection endow federal courts with a structural advantage. ${ }^{48}$ Federal judges are insulated from political pressures,

48 See MARTIN H. REDISH, FEDERAL JURISDICTION: TENSIONS IN THE ALLOCATION OF JUDICIAL POWER 1-6 (2d ed. 1990) (arguing that "[a]n individual should therefore be able to obtain judicial vindication of his federal rights in federal, rather than state court"); Neuborne, 
emboldening them to uphold meritorious, but unpopular, constitutional claims. Others argue that if federal courts were ever superior in constitutional adjudication, they no longer are. The authors of one empirical study claimed to find no significant difference in the results of state court constitutional adjudication versus federal court constitutional adjudication. ${ }^{49}$ The methodology of this study has since been questioned, suggesting that we are not close to determining whether any real difference exists. ${ }^{50}$

For purposes of my critique, however, the empirical reality is irrelevant. The received wisdom itself is premised on the belief of a preexisting disparity between state and federal court adjudication. As explained by Professor Bator, "It is not enough to assert that the federal forum may be the more hospitable forum; we must also create conditions for assuring that the state courts will become a more hospitable forum, that the rhetoric of parity becomes a reality." 51 If channeling federal constitutional claims to state courts is necessary to evoke a greater sense of responsibility in state judges, as Bator argues, does that not assume some sort of "responsibility deficit" in need of a cure? We would not need to strengthen the effectiveness of state court constitutional adjudication if its effectiveness was equal to that of federal court adjudication in the first place.

Champions of the received wisdom might respond that things already have changed. At one time, some state courts were less than hospitable toward certain federal constitutional claims, but that state of affairs has long ceased. Justice Powell stated this position explicitly in Stone v. Powell when he noted that "[d]espite differences in institutional environment and the unsympathetic attitude to federal constitutional claims of some state judges in years past, we are unwilling to assume that there now exists a general lack of appropriate sensitivity to constitutional rights in the trial and appellate courts of the several States." ${ }^{952}$ The received wisdom, therefore, could be rephrased in the following way: state court constitutional adjudication was once substandard, hence the need to strengthen such courts by

supra note 14, at 1128 (concluding that " $[t]$ his insulation factor ... explains the historical preference for federal enforcement of controversial constitutional norms"); Martin H. Redish, Judicial Parity, Litigant Choice, and Democratic Theory: A Comment on Federal Jurisdiction and Constitutional Rights, 36 UCLA L. REV. 329, 333 (1988) ("Can one realistically suggest that we can trust the independent judgment of [elected state judges] in cases challenging the constitutionality of state action?").

${ }^{49}$ See Solimine \& Walker, supra note 14, at 214 ("Our study indicates that state courts are no more 'hostile' to the vindication of federal rights than are their federal counterparts....").

${ }^{50}$ See Chemerinsky, supra note 14, at 261-69 (alleging methodological flaws in the Solimine \& Walker study).

51 Bator, supra note 40 , at 624.

52428 U.S. 465,494 n.35 (1975). 
channeling claims to them; however, state courts have since become the equal of federal courts, so individual rights presently are not being sacrificed.

Let us take stock of what this scenario entails. It explicitly concedes that state court adjudication was once deficient. It tacitly admits that the federal constitutional claimants shunted to state court in the early years were sacrificed for the improvement of state court process. The vindication of their rights was endangered for reasons unrelated to their own individual deserts. There is, of course, nothing we can do now about the sacrifices that were exacted in those early years before state court adjudication "caught up" to its federal court counterpart. We have no mechanisms for tracing or remedying those wrongs. But we must be alert to the possibility that doctrines like those announced in Younger v. Harris, ${ }^{53}$ Allen v. McCurry, ${ }^{54}$ and Stone v. Powell ${ }^{55}$ require continued sacrifices of individual constitutional claimants.

Let us examine the assumptions of the received wisdom as articulated by Professor Bator. First, it assumes that doctrines like those of Younger, Allen, and Stone work uniformly throughout the state court system. Second, it assumes that those doctrines effected a system-wide reform that cured all defects. If these assumptions are invalid, then it is possible that present-day constitutional claimants are still being sacrificed when they are channeled to state court.

Testing these assumptions requires a thorough examination of state court adjudicative malfunction. As explained by Professor Bator, it was not inferior intelligence or training, nor lack of insulation against political pressure, nor simple racial animus that made state court constitutional adjudication deficient. It was an inability or disinclination to "internalize the sense that they, too, speak for the Constitution-that it is their Constitution." ${ }^{\text {"56 I }}$ interpret this to mean that state judges tend to be more provincial in their outlooks. Whether it is because of the selection process or institutional mindset, state judges tend to identify more with state law than federal law. Channeling a steady stream of federal constitutional claims into their dockets erodes this provincial mindset and eventually acculturates these judges into the national community of constitutional values.

The problem now becomes evident. The "cure" for provincialism does not operate on an institutional level. It operates at the level of individual judges. Different judges are "cured" at different rates. Some may be ac-

\footnotetext{
53401 U.S. 37 (1971).

54449 U.S. 90 (1980).

55428 U.S. 465 (1976).

56 Bator, supra note 40, at 625.
} 
culturated into the national community of constitutional values after a few months of handling constitutional litigation; some may take years. The critical observation here is that the state court system has not been "cured" of its provincialism once and for all. The system contains thousands of individual judges who are constantly getting on line, being acculturated at different rates, retiring, and being replaced. At any given time, there are sure to be a number of newer state judges who have not yet embraced national constitutional values.

In the end, the individualist critique of the received wisdom escapes this first objection relatively unscathed. Taking Professor Bator's story seriously, we are forced to conclude that, at any time, there will be some number of state judges whose constitutional adjudication will be deficient because of their provincialism. No amount of channeling constitutional claims into their dockets can change that fact. Thus, the maintenance of doctrines like those of Younger, Allen, and Stone will always endanger the vindication of constitutional rights for reasons unrelated to individual desert. Some claimants will always be sacrificed for the greater goal of improving state court adjudication.

\section{B. Do Western Liberal States Already Sacrifice Individual Rights?}

Another objection to the individualist critique of the received wisdom is that it ignores the innumerable areas in which western liberal democracies encumber individual rights for the benefit of the collective good. In essence, this objection challenges the premise set forth in Part II. It denies that western liberal democracies make any sincere attempts to treat individuals as ends in themselves, rather than as means to societal ends.

I have already conceded that my arguments have no force if the individualist premise is rejected. If government is free to treat the denial of individual rights as no different than creations of disutility, then there is nothing suspect about sacrificing present-day constitutional claimants for the greater protection of future claimants. There simply is no way to prove the truth or falsity of the individualist premise. The premise rests on contestable characterizations of doctrines and institutions. In the end, the individualist premise either resonates with our experience and impressions or it does not.

Before conceding the impossibility of rational discourse on this score, however, I would like to sketch the contours of the individualist premise in finer detail. The premise is not that western liberal governments never-or even rarely-sacrifice individual rights for the collective good. Countless examples of such actions exist. Instead, the premise is that sacrificing individual rights for the collective good is generally disfavored by the dominant 
political culture. Governments must produce an extra-satisfying explanation for why it is necessary to deprive someone of her rights. A heavy justificatory burden always lies on the shoulders of those who would subordinate individual rights to the larger good.

In light of this premise, let us examine some of the more prominent occasions in which the liberal state sacrifices individual rights for societal betterment. Forced conscription is perhaps the most extreme example. Such conscription is usually limited to wartime, however. ${ }^{57}$ The State usually falls back on this expedient only when the very existence of the collectivity is imperiled. When conscription is used to wage a war that does not appear necessary to preserve the Nation's existence, such as in Vietnam, it meets with great moral condemnation.

Regulatory schemes are everywhere in American life, and they all limit individual freedom in the name of public safety, protection of the environment, protection of consumers, and so forth. Zoning is a case in point. Zoning "is virtually universal in the metropolitan areas of the United States." 58 Municipalities maintain all sorts of height, area, and use restrictions. Zoning ordinances generally have been upheld as a valid means of protecting public health, safety, and even "the appearance and environment of [a] rural high-class residential community." owners are forced to sacrifice their rights for the betterment of the community. Can this be reconciled with what I have described as the individualist premise of American political and legal culture?

I confess some impulse to chalk up zoning as an aberration in American society, perhaps partially explained by the mad rush of economic development at the turn of the century, and by the fact that only property, and not liberty, is at stake. But we should not be too hasty in conceding that zoning is altogether inconsistent with the notion that individual rights should not be sacrificed entirely for the general good. First, there is a point beyond which comprehensive use restrictions cease to be noncompensable regulations and become compensable takings. If a zoning ordinance were to deny any economically viable use of the land, it would almost certainly constitute a taking. ${ }^{60}$

57 The exception would be the continued conscription following World War II.

58 Robert C. Ellickson, Alternatives to Zoning: Covenants, Nuisance Rules, and Fines as Land Use Controls, 40 U. CHI. L. REV. 681, 692 (1973).

${ }_{59}$ Elbert v. Village of N. Hills, 28 N.Y.S.2d 317, 318 (Sup. Ct. 1941), rev'd on other grounds, 28 N.Y.S.2d 172 (1941). See generally Developments in the Law-Zoning, 91 HARV. L. REV. 1427 (1978) (discussing social policies of zoning and alternatives).

${ }^{60}$ Cf. Pennsylvania Coal Co. v. Mahon, 260 U.S. 393, 415-16 (1922). Speaking for the Court, Justice Holmes stated: 
Most importantly, however, most zoning restrictions effect what Justice Brandeis termed "an average reciprocity of advantage' as between the owner of the property restricted and the rest of the community." ${ }^{261}$ Put simply, everybody receives important benefits from zoning, even those individuals whose property rights are sharply curtailed. A building height restriction diminishes a property owner's freedom, but the property owner will benefit by way of light, air, and view from the fact that surrounding property owners are similarly restricted. Even use restrictions confer reciprocal benefits. I cannot use my property for commercial purposes, but neither can any of my neighbors, and that largely supports the value of my property. In this sense, the individual subject of a zoning ordinance somewhat resembles a member of an involuntary cartel. Richard Epstein has cogently argued that all zoning effects a taking, but that the reciprocity of advantage constitutes compensation. ${ }^{62}$ The Supreme Court has cited the presence of reciprocity of advantage as a reason for upholding a zoning ordinance. ${ }^{63}$ Reciprocity of advantage also explains why the progressive income tax is not inconsistent with the individualist premise. ${ }^{64}$ Tax revenue supports the infrastructure that makes it possible for people to earn large

The general rule at least is, that while property may be regulated to a certain extent, if regulation goes too far it will be recognized as a taking .... We are in danger of forgetting that a strong public desire to improve the public condition is not enough to warrant achieving the desire by a shorter cut than the constitutional way of Id. paying for the change.

Recently, there has been a renewed vigor in the Supreme Court's protection of property rights against some zoning ordinances. See Dolan v. City of Tigard, 512 U.S. 374, 386-96 (1994) (holding that the city's dedication requirement, including the dedication of land for a public greenway and for a pedestrian/bicycle pathway, attached to a petitioner's application to expand her store and pave a parking lot, constitutes an uncompensated taking of property); Lucas v. South Carolina Coastal Council, 505 U.S. 1003, 1020-32 (1992) (finding that a taking claim is ripe where two years after land was purchased a restriction barred the purchaser of the land from erecting any permanent habitable structures on the land); Nollan v. Califormia Coastal Comm'n, 483 U.S. 825, 838-42 (1987) (holding that a state commission's imposition of an access-easement condition to the application of a building permit cannot be treated as an exercise of land use regulation power because the condition does not serve public purposes related to the permit requirement).

61 Mahon, 260 U.S. at 422 (Brandeis, J., dissenting).

62 See RICHARD A. EPSTEN, TAKINGS: PRIJATE PROPERTY AND tTE POWER OF EMINENT DOMAIN 195-215 (1985) (asserting that the state may provide compensation either explicitly, in the form of cash or property, or implicitly).

63 See Agins v. City of Tiburon, 447 U.S. 255, 262 (1980) (noting that an ordinance benefited "appellants as well as the public by serving the city's interest in assuring careful and orderly development of residential property with provision for open-space areas").

${ }^{64}$ But cf. Calvin R. Massey, Takings and Progressive Rate Taxation, 20 HARv. J.L. \& PUB. POL'Y 85, 88 (1996) (arguing that progressive income taxation is unconstitutional). 
sums of money. High-earning people derive greater benefit from this infrastructure than low-earning people.

If the individualist premise were that the liberal state never requires individuals to sacrifice rights for the greater good, it would be untenable. In any mass society, some compromises must be made and some people will fall between the cracks. But the liberal state makes a sincere attempt to treat people as ends in themselves rather than purely as means to collective ends. It does not move forward with programs that will lead to large-scale deprivations of rights unless there exists reciprocity of advantage or great social exigency, or both. That is the problem with the received wisdom in federal courts law. It fails to treat individual constitutional claimants as ends in themselves. It channels large numbers of them to state court, where they are subjected to deficient process, without reciprocity of advantage or great social exigency.

\section{Does the Received Wisdom Sacrifice Individual Rights?}

The most pressing objection to the individualist critique is that no one has a right to litigate in federal court. ${ }^{65}$ One may be entitled to a remedy for the substantive constitutional violation complained of, but one is not entitled to have that remedy issued by any particular court. And if no one has a right to litigate in federal court, then there is nothing wrong with channeling claimants to state courts for the collective good.

Let us examine the statement, "No one has a right to litigate in federal court." This feels right, but why? One possibility is that individuals have no right to a particular type of process-that is, there are no "procedural" rights. This statement, however, is demonstrably incorrect. The Constitution guarantees a right to due process in connection with the deprivation of life, liberty, or property. ${ }^{66}$ Criminal defendants have a right to a jury trial. ${ }^{67}$ These are rights to certain types of processes.

The concept of a "right to litigate in federal court," then, is not unintelligible. We must, however, clarify what is meant by "right." If "right" connotes an entitlement to a remedy for violation, then there is no right to litigate in federal court. For example, if a federal judge wrongly remands a case that has been removed from state court, the plaintiff has no remedy.

${ }^{65}$ See Henry M. Hart, Jr., The Power of Congress to Limit the Jurisdiction of Federal Courts: An Exercise in Dialectic, 66 HARV. L. REV. 1362, 1363 (1953) (proposing that the Constitution does not provide a "right to proceed or be proceeded against, in the first instance, in a federal rather than a state court").

66 See U.S. CONST. amend. V.

67 See U.S. CONST. amend. VI. 
She cannot sue the federal judge for damages, obtain an injunction to force the federal judge to rescind the remand, or even appeal the remand to a federal appellate court. She has no legally cognizable right to maintain her suit in federal court.

This is the right answer to the wrong question. The individualist premise holds that the liberal state normally does not sacrifice any individual right for the benefit of the greater good. The right need not be legal; it could be moral or political, as long as it runs against the state. We all hold moral or political rights against the state that are legally unenforceable. For example, each of us has a moral right not to be treated arbitrarily by the government, yet the Due Process and Equal Protection clauses may or may not reach a particular situation. Each of us has a political right to participate fully in the democratic process, yet the First Amendment may or may not cover a particular situation. Insofar as philosophical inquiry is concerned, these rights are no less substantial simply because they spring from moral or political imperatives rather than legal imperatives.

I use the term "right" in Ronald Dworkin's sense, that rights are "trumps." Fo For Dworkin, a right is an individual preference that trumps other preferences. ${ }^{69}$ If an individual preference is given no more weight in a utilitarian calculus than other preferences, it cannot be called a "right" in the Dworkinian sense. For example, suppose A would like to be able to drive south on Lexington Avenue, while a majority of others want it to be oneway due north. ${ }^{70}$ In the normal case, we can say that $A$ has no right to drive south on Lexington Avenue because his preference will be weighed no differently from that of anyone else. If, on the other hand, we were to suppose that $\mathrm{A}$ had deeded land to the city only after obtaining a promise that Lexington Avenue would remain a two-way street in perpetuity, $A$ would now be said to hold a right. A's preference to keep Lexington Avenue two-way will be weighed more heavily than the ordinary citizen's preference to make Lexington Avenue one-way. Of course, a person's preference may be given more weight because of reasons unrelated to "right"-say, because he has great political muscle. We can, however, at least say that a person has no right if his preference in the matter is not given any special weight. ${ }^{71}$

68 DWORKIN, supra note 19, at Xv (referring to rights as "trumps over collective goals").

69 See Donald H. Regan, Glosses on Dworkin: Rights, Principles, and Policies, in RONALD DWORKIN AND CONTEMPORARY JURISPRUDENCE 119, 120-22 (Marshall Cohen ed., 1983) (discussing the idea of "rights as trumps").

70 See id. at 121 (discussing what Regan refers to as Dworkin's "Lexington Avenue argument").

${ }^{71}$ See id. ("To say that there is a right to something is ... to say that a preference for that something gets some extra weight."). 
Having so defined the term "right," here is the question: Can one have a moral or political right to litigate in a particular forum? To illustrate why the answer is clearly yes, I pose an exaggerated hypothetical. Suppose D is prosecuted for the murder of $\mathrm{V}$. There are only two trial judges in the jurisdiction, $\mathrm{X}$ and $\mathrm{Y}$. Judge $\mathrm{X}$ does not know $\mathrm{D}$, but Judge $\mathrm{Y}$ is $\mathrm{D}$ 's archenemy from college. By random draw, the case is assigned to Judge $Y$.

Normally, we would all agree that a person has no right to have her case tried before a particular judge. But in this case, D plainly has a moral or political right not to have the case tried before Judge $Y$. We can say that $D$ has a "right" in this situation because her preference will be given special weight in the utilitarian calculus of whether to try her before Judge $X$ instead of Judge $Y$. Even if we find out that Judge $X$ is on a month-long vacation to Cancun, Judge $X$ 's courtroom is currently under renovation, and both the prosecutor and Judge $Y$ would very much prefer the case to be tried before Judge $Y$, the case will be tried before Judge X. D's preference not to be tried before a judge who obviously will be biased will trump the preferences of others.

In this extreme hypothetical, $D$ 's right to be tried before Judge $X$ is almost absolute. Virtually no consideration in favor of trying the case before Judge $Y$ could overcome it. Note, however, that rights are almost never absolute. ${ }^{72}$ For example, the right not to have others trespass on your property gives way in an emergency, such as when officials have to dig a fire line. Rights to free speech can be defeated by extraordinary claims of national security. To say that a right must have trumping power does not specify how much trumping power it must have. ${ }^{73}$ There are relatively strong rights and relatively weak rights. ${ }^{74}$ If the preference carries any trumping power, it constitutes a right.

It should now be clear why, for purposes of our analysis, federal constitutional claimants have a right to litigate in federal court. By the received wisdom's own hypothesis, there is something about state court constitutional practice that needs to be improved. State court judges are initially too provincial in their outlook and do not sufficiently identify with federal law. Compared to federal courts, there is an increased danger that the claimants'

${ }^{72}$ Cf. DwORKIN, supra note 19, at 92 ("Rights may also be less than absolute; one principle might have to yield to another, or even to an urgent policy with which it competes on particular facts.").

${ }^{73}$ See Regan, supra note 69, at 121 ("To say that there is a right to something is only to say that a preference for that something gets some extra weight. It is not to say anything about how much extra weight.").

74 See id. at 122 (explaining that "a right which guarantees the preference it protects only a little extra weight is a weak right," and that a strong right is one that "confer[s] a great deal of extra weight on the preferences [it] protect[s]"). 
substantive constitutional rights will not be upheld. The federal constitutional claimant has a right to litigate in federal court for the exact same reason that $D$ had a right to be tried before Judge $X$. In each of these situations, only two procedural avenues are available, and one of them is deficient. To be sure, contemporary state court constitutional practice is nowhere as deficient as Judge $\mathrm{Y}$ is in my hypothetical. But this difference in degree of procedural deficiency does not alter the fact that it confers a right on the claimant to litigate in the alternative forum. It means only that the right of a federal constitutional claimant to litigate in federal court is not nearly as strong as D's right to be tried before Judge $X$. The typical federal constitutional claimant's right to litigate in federal court does not have as much trumping power as does D's right to be tried before Judge $\mathrm{X}$.

I have now fully replied to the objection that one has no right to litigate in federal court. Assuming, as we must, that state court constitutional practice is deficient to some degree, federal constitutional claimants have a moral or political right to litigate in a nondeficient forum. I have conceded that this right is relatively weak; it is capable of being trumped by something less than the greatest social emergency. So, although we are finished with the three objections to the individualist critique, my response to the third objection naturally inspires the ultimate question: Isn't the relatively weak right to litigate in federal court outweighed by the social need to strengthen state courts?

Based on the assumptions made by the received wisdom, the answer is no, and it will always be no because the only reason for strengthening state courts is the same reason supporting federal constitutional claimants' right to litigate in federal court. The deficiency of state court constitutional practice gives rise to a need for improvement, but it also triggers the claimant's right to litigate in a nondeficient forum, and to the exact same degree. This is an argument that advocates of the received wisdom simply cannot win. If they posit very minor flaws in state court practice, then the right to litigate in federal court becomes very weak, but the social need for improvement also shrinks to virtually nothing. If they posit deep flaws, the social need for improvement becomes great, but the right to litigate in federal court acquires great trumping power. Under the individualist premise, which tilts the playing field in favor of the individual and requires the government to carry the burden of demonstrating satisfactory justification, this standoff will always result in the individual claimant being declared the victor. As long as the need to improve state court adjudication is the sole justification for channeling constitutional claims into state court, the received wisdom will run afoul of the individualist premise. 
Thus, the received wisdom-as articulated by Justices Black and O'Connor and Professor Bator-must fall back on claims about positive law, history, and practical exigency. I reiterate that this is not the place to question those claims; that has been done elsewhere. ${ }^{75}$ My conclusion is that the argument for the received wisdom draws no support from normative political philosophy.

\section{THE AFFIRMATIVE CASE FOR A FEDERAL NORM}

In the previous Part, I concluded that normative political philosophy does not support the program of channeling federal constitutional claims to state courts. If that conclusion is correct, the next issue is whether normative political philosophy supports some other norm governing the allocation of claims between federal and state courts. I take up that inquiry in this Part.

Before proceeding, however, I wish to reiterate the logical severability of this Part from the previous one. Even if I am wrong, and political philosophy does lend some support to the received wisdom, it is logically possible for political philosophy also to lend some support to an alternative principle for allocating federal constitutional claims between the two judicial systems. Just as the text, history, and structure of a constitutional provision may lend some support to the view that a particular governmental practice is unconstitutional, and some support to the view that it is not unconstitutional, political philosophy may lend some support to the received wisdom and some support to a mutually exclusive allocation norm. Therefore, this Part should hold the interest even of those who disagree with my critique of the received wisdom.

In this Part, using the individualist premise set forth in Part I, I will inquire into whether political philosophy supports what I refer to as the "federal forum" norm. The federal forum norm holds that federal constitutional claimants generally should be entitled to at least one plenary hearing in federal court. I shall set the federal forum norm in opposition to what I will refer to as the "state court primacy" norm. The state court primacy norm holds that state courts should generally have the final say on federal consti-

75 In my opinion, some of the legal, historical, and practical critiques of the received wisdom are quite powerful. See, e.g., Amar, A Neo-Federalist View, supra note 14, at 206 (arguing that the Framers did not intend to require the creation of lower federal courts, but instead required that some federal court be available "to hear and resolve finally any given federal question, admiralty, or public ambassador case"); Neuborne, supra note 14, at 1117-30 (challenging the Supreme Court's assumptions that "no factors exist which render federal district courts more effective than state ... courts for the enforcement of federal constitutional rights"). 
tutional claims as long as the state courts provide a full and fair opportunity for the claimants to be heard.

Borrowing from the analytical framework of John Rawls's $A$ Theory of Justice, ${ }^{76}$ I propose a thought experiment in which rational people in a generic liberal democracy, pursuing their perceived self-interest under a veil of ignorance, are asked to choose between the federal forum norm and the state court primacy norm. I will attempt to demonstrate why such rational people would select the federal forum norm. The significance of this choice is that it suggests that political philosophy lends at least some support to the federal forum norm.

\section{A. A Rawls Primer}

Because I adopt significant elements of Rawls's analytical framework, a brief survey of his theory is in order. In A Theory of Justice, Rawls set forth definitive principles of justice-that is, principles around which just societal institutions would be structured. In keeping with the liberal credo, Rawls deduced these principles of justice from a neutral procedure. ${ }^{77}$ Rawls laid out this procedure in an elaborate thought experiment. He asked his readers to imagine a pre-societal situation in which free, rational, and equal persons were required to agree on the principles by which their social and political institutions would be governed. ${ }^{78}$ He referred to this situation as the "original position." ${ }^{\text {79 }}$ During these deliberations, the participants are deprived of knowledge about their own personal characteristics: wealth, social station, race, gender, physical ability, life experience, philosophy of life. Indeed, they do not even have sufficient information from which to deduce the odds that they will be rich or poor, black or white, male or female, influential or powerless, once they enter society. ${ }^{80}$ The participants know only the most general propositions about human nature, social behavior, and economics. ${ }^{81}$ Rawls referred to this blackout of knowledge about personal circumstances

76 RAWLS, supra note 18.

77 Of course, some have charged that Rawls's procedure is both value-laden and resultoriented. See, e.g., Thomas M. Scanlon, Jr., Rawls' Theory of Justice, 121 U. PA. L. REV. 1020,1074 (1973) (arguing that "Rawls has loaded the odds fairly heavily" in favor of his view of "how rational beings would behave in the "original position").

${ }^{78}$ See RAWLS, supra note 18, at 11 ("They are the principles that free and rational persons concerned to further their own interests would accept in an initial position of equality as defining the fundamental terms of their association.").

79 Id. at 12 .

${ }^{80}$ See id. at 12-13 (arguing that morally irrelevant factors that would unfairly bias the choice of the basic principles of society should be excluded from the original position).

81 See id. at 137 ("They understand political affairs and the principles of economic theory; they know the basis of social organization and the laws of human psychology."). 
as the "veil of ignorance." A further stipulation of the original position is that participants may agree only to such principles of justice by which they could abide, no matter where they end up within the society when the veil has been lifted. ${ }^{83}$ This stipulation-combined with the radical uncertainty brought about by the veil of ignorance-forces the parties into a risk-averse decisional strategy. Because they must be able to live with the principles they choose, and because they have no idea where in society they will land, they must decide on the basis of which principle or set of principles yields the least dismal worst-case scenario. In other words, they must first determine the worst-case scenario for themselves under each possible principle or set of principles. They must then compare the various worst-case scenarios and select the principle or set of principles whose worst-case scenario is the least bad. Rawls refers to this risk-averse decision strategy as the "maximin" strategy. ${ }^{84}$

Next, the various candidates are laid before the parties for their consideration. The parties are to choose from various permutations of utilitarianism, perfectionism, intuitionism, egoism, and Rawls's unique blend of liberty and equality. ${ }^{85}$ Rawls argued that the parties would choose his proffered principles, which consisted of the following: (1) "each person is to have an equal right to the most extensive basic liberty compatible with a similar liberty for others" (the "liberty principle"); and (2) "social and economic inequalities are to be arranged so that they are both (a) reasonably expected to be to everyone's advantage, and (b) attached to positions and offices open to all" (the "difference principle"). ${ }^{86}$ These principles are lexically ordered, giving priority to the liberty principle. ${ }^{87}$

${ }^{82}$ Id. at 12 .

83 See id. at 137 ("[The persons in the original position] must choose principles the consequences of which they are prepared to live with whatever generation they turn out to belong to.").

See id. at 150 (arguing that although maximin is analogous to the pair-wise comparisons of worst-case scenarios, the informational constraints on the original position, combined with the requirement that deviations from equality must also be to the advantage of the least well off in society, make it rational to choose the two principles of justice).

${ }^{85}$ See id. at 122-26 (arguing that the parties choose among a small set of traditional accounts of justice because, left to their own devices given the constraints of the original position, there is no assurance that they will articulate the more plausible conceptions).

${ }^{86}$ Id. at 60 . I have quoted Rawls's provisional formulation of the two principles because they are more accessible to the uninitiated, and because the precise content of the principles is unimportant to my argument. For the record, Rawls's final formulation of the two principles of justice is:

[(1)] Each person is to have an equal right to the most extensive total system of equal basic liberties compatible with a similar system of liberty for all. ... [ [and (2)] Social and economic inequalities are to be arranged so that they are both: (a) to the greatest benefit of the least advantaged, consistent with the just savings principle, 
Rawls did not stop with the explication of the two principles of liberty. He then proceeded to test them for their practical feasibility. "Some measure of agreement in conceptions of justice is ... not the only prerequisite for a viable human community," he wrote. ${ }^{88}$ "There are other fundamental social problems, in particular those of coordination, efficiency, and stability." ${ }^{89}$ Rawls considered these last three items to be matters of feasibility. Whatever principles of justice are selected in the original position must allow citizens to coordinate their activities. ${ }^{90}$ They should lead to the achievement of social ends in a relatively efficient manner. ${ }^{91}$ And they should be capable of creating a scheme of social cooperation that is relatively stable. ${ }^{92}$ Thus, roughly the last third of $A$ Theory of Justice was devoted to feasibility, principally to questions of stability. ${ }^{93}$

I propose to adopt portions of the Rawlsian framework in the following manner. I adopt the notion of an original position, although, of course, not for the purpose of selecting principles of justice. The parties in our original position will be selecting a generic forum allocation rule for the court system in a constitutional democracy. The parties will be placed under the veil of ignorance; however, our use of the veil necessarily differs in some respects from Rawls's. First, the parties know that they are selecting a court structure for a representative and constitutional democracy of some sort. They do not know the structure of government or the content of the constitution, but they do know that it establishes minimum rights that may not be violated. Second, the parties do not (at this stage) know anything about the actual history or experience of the United States or any other country operating under a federal system. The parties' choice of a forum allocation rule in the original position will be tested against actual experience at a later stage of analysis. In selecting a forum allocation rule, the parties will be re-

and (b) attached to offices and positions open to all under conditions of fair equality of opportunity.

Id. at 302 .

87 See id. at 61 (noting that because the first principle of justice must be fully satisfied before considering the second principle, there can be no trade-off of less of the second principle to gain more of the first).

${ }^{88}$ Id. at 6.

89 Id. at 6.

90 See id. at 133 (arguing that the principle of justice must "support the stability of social cooperation").

91 See id. at 65-75 (discussing the principle of efficiency).

92 See id. at 454 (discussing the well-ordered society).

93 See ChandRan KuKathas \& PHILIP PETTT, RAWLS: A THEORY OF JUSTICE AND ITS CRITICs 146 (1990) (arguing that Rawls is trying to foster "agreement on the way basic social institutions should be arranged if they are to conform to the freedom and equality of citizens as moral persons"). 
quired to use the maximin rule of decision. Of the alternative court systems presented to them, the parties must select the system that presents the least bad, worst-case scenario.

Finally, the forum allocation rule chosen in the original position must be stable. It must be capable of generating respect among the general population. This means that the resulting court system must be capable of rendering judgments and pronouncements in a voice sufficiently authoritative to settle existing disagreements and prevent future ones. Also, a court system constantly at war with itself will not meet the requirement of stability.

\section{B. The Veil of Ignorance}

What court system would Americans choose for themselves after a typical American political campaign? Eastern liberal democrats might favor a unitary court system because of the general experience of the Warren Court, or, more particularly, because of Brown v. Board of Education ${ }^{94}$ and Roe v. Wade. ${ }^{95}$ Republicans and conservative southern democrats might favor a dual system because of its potential to unleash state police powers. More particularly, conservatives might oppose a unitary system because of Roe v. Wade and, perhaps, Mapp v. Ohio. ${ }^{96}$ Or, clever campaign advertising might reverse these respective positions. Liberal democrats might be persuaded that civil rights and civil liberties would flower best in a decentralized system, where state supreme courts could protect individual rights more aggressively than a central supreme court. ${ }^{97}$ Republicans might be persuaded that-notwithstanding the Warren Court-federal Supreme Court appointments will tend to be more conservative than state supreme court appointments because Republicans tend to win the White House more often than they win a majority of state houses. This would be an interesting question for pollsters and political pundits.

I submit, however, that the answer to that question would not be of much value to the law. Interest group politics may be adequate for the tasks of electing representatives and enacting transient legislation, but they are too shortsighted and partisan to handle the foundational structuring of an enduring judicial system. We should not be designing the basic structure of

94347 U.S. 483 (1954).

95410 U.S. 113 (1973).

96367 U.S. 643 (1961).

97 Cf. William J. Brennan, Jr., State Constitutions and the Protection of Individual Rights, 90 HARV. L. REV. 489, 491 (1977) (arguing that state constitutions are just as integral to the full protection of individuals' rights as is the Federal Constitution). 
the judicial system around a few high-profile decisions. Discourse about the structure of our court system should transcend narrow partisan politics and myopic interest-group foci. It should be based on a far-sighted view of rational persons in a position of equality. The veil of ignorance forces decision makers to take a broad, far-sighted view of things by denying them knowledge essential to a narrowly partisan perspective.

Rawls described the scope of the veil as follows:

First of all, no one knows his place in society, his class position or social status; nor does he know his fortune in the distribution of natural assets and abilities, his intelligence and strength, and the like. Nor, again, does anyone know his conception of the good, the particulars of his rational plan of life, or even the special features of his psychology such as his aversion to risk or liability to optimism or pessimism. More than this, I assume that the parties do not know the particular circumstances of their own society. That is, they do not know its economic or political situation, or the level of civilization and culture it has been able to achieve. The persons in the original position have no information as to which generation they belong.... They must choose principles the consequences of which they are prepared to live with whatever generation they turn out to belong to. ${ }^{98}$

What, then, do the parties in the original position know? They know only the most general facts about the world and humanity:

They understand political affairs and the principles of economic theory; they know the basis of social organization and the laws of human psychology. Indeed, the parties are presumed to know whatever general facts affect the choice of the principles of justice. There are no limitations on general information, that is, on general laws and theories, since conceptions of justice must be adjusted to the characteristics of the systems of social cooperation which they are to regulate, and there is no reason to rule out these facts. ${ }^{99}$

In $A$ Theory of Justice, Rawls deprives the parties of knowledge about their society's "political situation." This means that the parties do not know what type of government their society has adopted, whether constitutional democracy, authoritarian, monarchy, or so on. In response to criticisms that this approach was too abstract and strove for too high a degree of universality, ${ }^{100}$ Rawls appears to have relented somewhat on this point in subsequent writings. By one interpretation, at least, Rawls now asserts that the purpose of the original position is "to find, not universal principles of justice, but

98 RAWLS, supra note 18, at 137.

99 Id. at 137-38.

100 See, e.g., ROBERT PAUL WOLFF, UNDERSTANDING RAWLS: A RECONSTRUCTION AND CRITIQUE OF A THEORY OF JUSTICE 179 (1977). 
principles appropriate for modern societies like the United States."101 Whether or not Rawls has actually changed his mind, parties asked to select a court system should be told the general form of government in their society. If a single philosopher-king with virtually plenary power governs the society, it can safely be deduced that the most rational court system will be a unitary one. This is because the structure and animating purpose of courts follows, at least to a considerable degree, from the polity's constitutive form of government. $^{102}$

Therefore, the parties in the original position should be told the general form of government in their society. They should be told that the government is a constitutional democracy with one central government and several provincial governments. This information, of course, begs many further questions. What is "democracy"? What is the content of the "constitution"? What is the relationship between the central and provincial governments? Unfortunately, these questions can be answered only in the most general ways, if at all. The parties can perhaps be told that democracy, in its most generic sense, denotes a polity in which there is some form of popular control over the government. ${ }^{103}$ On this we can all agree. A more specific definition of democracy, however, would provoke controversy and partisanship. Likewise, the parties can be told that the constitution adumbrates governmental structure and stipulates certain minima of individual rights. But they will not be informed of the specific content of constitutional provisions, because knowledge of those provisions would provoke partisan bickering over the meaning of phrases like "equal protection of the laws"; "due process"; ${ }^{105}$ "Privileges and Immunities"; ${ }^{106}$ and perhaps the Tenth Amendment, which states that "powers not delegated to the United States by the Constitution, nor prohibited by it to the states, are reserved to the States

101 KuKathas \& PETTr, supra note 93, at 123; see also JOHN RAWLS, POLITICAL LIBERALISM 26 (1995) (explaining that the original position is a "way to elaborate a political conception of justice" and to evaluate society's convictions).

${ }^{102}$ See MiRJan R. DAMAŠKa, THE FACES OF JUSTICE AND STATE AUTHORITY: A COMPARATTVE APPROACH TO THE LEGAL PROCESS 71-96 (1986) (exploring "two contrasting dispositions of governments: the disposition to manage society and the disposition merely to provide a framework for social interaction"); MARTIN SHAPIRO, COURTS: A COMPARATIVE AND POLITICAL ANALYSIS 17-28 (1981) (discussing social control and conflict resolution by courts).

${ }^{103}$ See RoBert A. DAHL, DEMOCRACY AND ITS CRITICS 1-9 (1989) (identifying the Greek origin of the word "democracy" as from "demokratia" with demos meaning people and kratia meaning rule or authority).

104 U.S. CONST. amend. XIV, $\S 1$.

105 U.S. CONST. amends. V \& XIV, $\S 1$.

106 U.S. CONST. art. IV, § 2. 
respectively, or to the people." 107 For much the same reason, the parties will not be instructed as to the "proper" relationship between the central and provincial governments. To launch them from that point of departure would be to defeat the purpose of the exercise. The point of the present project is to reconceptualize that relationship in the judicial context. The purpose of the reconceptualized court system, in turn, is to extract meaning from the grand phrases of the Constitution.

Some will argue that the parties in the original position ought to have as much information about their society as possible before agreeing to a court system. Before making any kind of important decision, they will argue, people should investigate the facts fully and survey all considerations in as synoptic a manner as possible. The parties should know the society's distribution of wealth, the racial composition of the population at large, and the distribution of racial minorities throughout different regions of the country. Most importantly, it will be argued, they should be apprised of the actual respective records of federal and state courts in race and gender cases, in business cases, in civil liberties cases, and so on. Once these chronicles of actual experience have been scrutinized, it will be argued, the parties will be in a position to make an intelligent and informed choice about which system to adopt.

The argument for a synoptic original position is flawed in several respects. First, as noted above, facts such as wealth and race distribution are subject to change over time. ${ }^{108}$ A judicial system must be designed for optimum performance over the long haul, not for a single moment in time. Because institutional inertia and legislative logrolling make it extremely difficult to adjust the system to constant demographic and political changes, we must take the long view. Second, if the parties are permitted to consider the complete histories of federal and state courts, the deliberations will deteriorate into an endless, formless rehash of anecdotes. For every story about how the Warren Court "reached out" beyond existing precedent to engage in "social engineering," there will be a story about how a Southern state court manipulated rules to discriminate against African Americans. For every story about how a federal district court heroically transformed unconstitutional state prison conditions into decent habitation, there will be a story about how a federal district court took over a school district and ran it into the ground. For every story about how a state court fumbled a complex legal issue, there will be a story about how a state court did justice for a deserving plaintiff whose case appeared deficient "on the papers." My point is

107 U.S. CONST. amend. X.

108 See supra text accompanying notes $89-99$ (discussing Rawls's principles of liberty and the changing places of individuals in his original position). 
simply that the parties in the original position have no framework for analyzing, digesting, and organizing these anecdotes into a usable form. If the parties are given the entire historical record at the outset, they will end up simply concluding that both federal and state courts have had great and awful moments.

Inundating a decision maker with the entire record all at once is not the best way to achieve a rational decision. Consider how a civil trial is conducted. ${ }^{109}$ The parties do not begin the case by introducing their documentary evidence and calling their witnesses. Each side develops a theory of the case and submits it to the court, initially in the form of points and authorities on motions to dismiss or for summary judgment, and eventually in trial briefs. When the court decides a motion to dismiss, it blinds itself to the actual facts of the case. It refuses to consider the defense counsel's protest that the allegations in the complaint are simply untrue. The court asks only whether a relatively vague set of allegations measures up to an abstract legal standard. If so, the court then proceeds to an orderly presentation of proofs. During the presentation of evidence, the court (in a bench trial) constantly gauges the evidence against two standards-the standard for liability under applicable substantive law (for example, that negligence consists of a want of ordinary care), and the quantum of evidence needed to carry the applicable burden of proof (for example, preponderance of the evidence). In other words, the court initially throws a sort of veil of ignorance over itself. When it emerges from the veil, it considers the facts only in accord with an analytical framework that has been worked out without reference to the particulars of the case at bar. Without the framework, the court would not know what to do with evidence as it was introduced.

A similar procedure should be employed for the present project. Just as a trial court must ascertain an applicable legal standard before it can meaningfully assimilate evidence, we must establish an analytical framework for assimilating evidence about the actual experiences of American judicial federalism. This framework must be created without reference to the expe-

109 Charles M. Yablon has noted that Rawls's methodology mimics the adjudicative paradigm:

Indeed, the attributes we have just defined as characterizing decisionmakers in the original position-rationality, lack of personal motives, general knowledge of human nature and society, and regard for the good of all members of society-are very close to the attributes we would hope to find in an ideal judge. The original position may be conceived then as an attempt to invoke in the reader those same attributes of idealized judging and then to persuade the reader, by convincing argument, that Rawls' conception of the fundamental principles of justice is to be preferred over competing conceptions.

Charles M. Yablon, Arguing About Rights, 85 MiCH. L. REV. 871, 879 (1987) (reviewing REX MARTIN, RAWLS AND RIGHTS (1985)). 
riences of federalism, because it ultimately will be used to evaluate those experiences. If we permit the experiences to shape the framework in the first place, the reasoning process will become circular. ${ }^{10}$

Therefore, in this Article, the hypothetical parties in the "original position" will select a basic court structure without any knowledge about their personal situations and without knowledge about the actual experiences of American judicial federalism. They will choose a court structure based entirely on general propositions about politics, sociopsychology, economics, and the like. Whichever court structure is chosen in the original position will have earned a presumption in its favor.

\section{The Maximin Rule of Decision}

The parties in Rawls's original position must select a set of principles of justice from several alternatives. More specifically, they must choose between Rawls's proffered principles (i.e., the liberty and difference principles) and the principle of average utility. In $A$ Theory of Justice, Rawls argues that the parties would use the maximin rule of decision, which would lead them to choose the liberty and difference principles over the principle of average utility. In this Subpart, I will argue that parties attempting to choose a basic court structure behind a veil of ignorance would use the maximin rule of decision. In the following Part, I will argue that adherence to the maximin rule would lead the parties to choose the federal forum norm over the state court primacy norm.

The maximin rule is one possible guide for decision-making under special conditions of partial uncertainty. Literally, "maximin" calls for the decision maker to maximize the minimum-that is, to select the least-harmful worst-case scenario. ${ }^{111}$ The decision maker should lay out all available options, calculate the worst-case scenario under each option, and then pick the option with the least harmful worst-case scenario. Assume for the moment that numbers represent some measure of a desired thing. ${ }^{112}$ If option 1 has a worst-case scenario of negative 7 , option 2 has a worst-case scenario of negative 8 , and option 3 has a worst-case scenario of positive 5 , then the maximin rule calls for us to select option 3 because positive 5 is a better result than negative 7 or negative $8 .^{113}$ Maximin ignores the fact that option 1

110 I concede that some degree of circularity may be inevitable. For example, Rawls's concept of "reflective equilibrium" appears to be circular to some degree.

111 See RAWLS, supra note 18, at 154 (discussing the maximin rule).

112 I will argue later that it makes a difference whether the objects of desire are worldly goods or individual liberties. See infra text accompanying notes 118-20.

113 See RAWLS, supra note 18, at 153-54 (applying the maximin rule to a hypothetical gain loss table). 
or option 2 may have a best-case scenario far superior to option 3. Maximin focuses exclusively on the worst-possible outcomes under each decision.

Rarely would we want to use the maximin rule to guide decisions in our everyday lives. ${ }^{114}$ Rawls states that the convergence of three factors makes maximin the appropriate rule of decision in a given situation. One factor is a lack of knowledge about probabilities. If the decision maker knew the relative likelihood of each outcome under each option, it would be rational to discount the result by the improbability of its occurrence. It is knowledge of likelihoods that usually makes maximin an inappropriate guide for everyday decisions. For example, the worst-case outcome of driving on the freeway is dying in a wreck. But the most probable outcome by far is arriving safely at one's destination, so we take the small risk of calamity in exchange for the considerable convenience of motor vehicle travel.

A. second factor in favor of applying maximin is that "the person choosing has a conception of the good such that he cares very little, if anything, for what he might gain above the minimum stipend that he can, in fact, be sure of by following the maximin rule." ${ }^{115}$ In other words, people sometimes perceive baselines below which they greatly fear falling, but above which they have little interest in ascending. An example of this might be found in term life insurance. Many people greatly fear falling below their present standards of living, and will go to considerable lengths to insure that their present standards of living can be maintained even under adverse circumstances. Few will purchase enough insurance, however, to increase their standards of living under adverse circumstances. For whatever reason, people do not desire improvements in standard of living as much as they fear declines.

Finally, maximin may be appropriate where some options present unacceptably bad worst-case scenarios. To take an extreme example, some people will choose unprotected sex over protected sex if the worst-case scenario under unprotected sex is pregnancy (remediable by abortion) and venereal disease (remediable by antibiotics), but will not make the same choice if the worst-case scenario is AIDS (presently incurable). It is rational to preempt options that present unacceptable outcomes such as death.

114 For example, Professor Rhoden criticized the use of maximin by obstetricians when deciding whether to perform Cesarean section operations. See Nancy K. Rhoden, The Judge in the Delivery Room: The Emergence of Court-Ordered Cesareans, 74 CAL. L. REV. 1951, 2021-22 (1986). This criticism is valid because both obstetrician and patient can estimate the probability of outcomes, which makes maximin an unsuitable decision strategy. The fact that maximin is unsuitable in the obstetric context does not make it unsuitable in other contexts.

115 RAWLS, supra note 18 , at 154. 
How many of the three factors must be present in order for maximin to become rational? Rawls contemplates what lawyers refer to as a "sliding scale." "Of course these features work most effectively in combination," according to Rawls. ${ }^{116}$ This statement implies that a high degree of one factor may excuse a lesser degree of another. For example, if all but one option present unacceptable worst-case scenarios, then maximin may be in order even if the decision maker has considerable (though less than total) knowledge of the likelihood of various outcomes.

Whether or not all three conditions exist in Rawls's original position-a matter of considerable controversy ${ }^{117}$ - they exist to a high degree in our version of the original position. First, there is ample reason to discount the probabilities of outcomes. The parties have only a sketchy idea of the distribution of outcomes throughout society. They know the worst outcome, the median outcome, and the best outcome. From that information, however, they cannot extrapolate the outcomes at, say, the fifteenth percentile. Assume option 1 yields a worst outcome of negative 7, a median outcome of positive 19 , and a best outcome of positive 20 . Assume option 2 yields a worst outcome of positive 5 , a median outcome of positive 6 , and a best outcome of positive 7. It would be tempting to choose option 1 on the notion that its median outcome is highly superior to that of option 2. But this inference would be unwarranted because one has no idea what outcome lurks between the worst case and the forty-ninth percentile. The outcome at the forty-ninth percentile might well be negative 7 ; there is no way to tell from the table.

One criticism surrounding Rawls's theory is that, as to primary goods, there is no baseline above which people become indifferent. Although Rawls is vague as to what the values in his tables represent, it is generally assumed that they represent some form of primary goods, such as money, influence, or social status. With limited exceptions, ${ }^{118}$ it is human nature to want as much of these items as possible. Our version of the original position presents one of those admittedly rare situations where the parties will care little for what they might gain above the minimum that can be guaranteed by adhering to the maximin strategy. This feature of our version of the original position distinguishes our version from Rawls's. The parties in our version of the original position do not seek primary goods. They seek indi-

116 RAWLS, supra note 18, at 154-55.

117 See, e.g., R.A. Musgrave, Maximin, Uncertainty, and the Leisure Trade-Off, 88 Q.J. ECON. 625, 627 (1974); James P. Sterba, Justice As Desert, 3 SOC. THEORY \& PRAC. 101, 104-09 (1974) (arguing that Rawls's original position lacks the third condition).

118 See infra note 125 and accompanying text (providing an example of an exceptional situation). 
vidual liberty and other individual rights, such as the right to be treated equally. It is not human nature to harbor a strong desire for an infinite amount of individual liberty. Most people would not be willing to gamble very much for a chance to gain the freedom to murder others with impunity, to defame them, or to discriminate against them on the basis of their race. Indeed, they would gamble little for a chance to use illegal drugs with impunity, or to drive as fast as they wished without fear of punishment. They might desire these freedoms if they were costless, but they would not risk much for a chance at them. If the flip of a coin were to decide whether they could drive as fast as they wanted or not at all, virtually all of them would decline the bet. This is not to say that they are all deeply risk averse. It is merely to say that our conception of the good places relatively little value on liberty beyond a certain baseline. ${ }^{119}$ They greatly cherish what they consider fundamental freedoms, even though they may disagree about which freedoms are fundamental. For example, all would consider freedom of thought fundamental. Most would consider freedom of worship and travel to be fundamental, as well as freedom from arbitrary governmental intrusion. Many or most would consider reproductive and child-rearing freedoms to be fundamental. But beyond this point, agreement on the desirability of particular freedoms sharply declines. People would be far less willing to gamble for freedoms beyond this threshold. ${ }^{120}$ Not many will gamble their freedom of thought or worship for the freedom to smoke in restaurants or to ride a motorcycle without a helmet. Therefore, the second of Rawls's conditions for the applicability of maximin is met in our version of the original position.

The third condition-that alternative strategies might lead to totally unacceptable outcomes-does not apply with the same force as the first two conditions. The most obvious example of a totally unacceptable outcome is slavery. If one or more of the options might lead to a regime in which slavery is tolerated or even state-mandated, then it would be rational to eliminate those options at the outset. This condition does not apply in our version of the original position. It is certainly true that slavery might be countenanced in a society with a relatively decentralized system of courts, but it is also true that it might be tolerated in a society with a centralized system of courts. It is more likely that slavery will come about in a society

119 What accounts for the difference in our attitudes toward primary goods versus liberty? Though this question deserves individual attention, the answer may have something to do with our perception of goods as positive assets and liberties as negative rights.

${ }_{120}$ Some will want to argue here that I have just proven the need for federalism, where the citizens of each state can set their own levels of freedom. Just the opposite is true. Because we value additional freedom beyond a certain point so little, there is no incentive to gamble for it. 
where provincial legal systems have a substantial degree of autonomy, because such a system permits more diversity of social structures, both egalitarian and nonegalitarian. Thus, the third condition for the applicability of the maximin rule of decision applies to our version of the original position to some degree. Overall, on a sliding scale, our version of the original position presents a fairly strong case for the use of maximin.

It is necessary to comment on the many criticisms that have been aimed at Rawls's use of the maximin rule. It has been said that the application of maximin in $A$ Theory of Justice is the weakest argumentative link in the entire book. ${ }^{121}$ A common complaint about Rawls's use of maximin is that many people are not really as risk averse as maximin makes them out to be. ${ }^{122}$ As a description of how people would truly react in the original position, critics argue that maximin underpredicts people's willingness to take risks. Professor Brian Barry sums up this critique:

\begin{abstract}
A man with a neutral attitude to risk will rationally accept a small risk of a catastrophic outcome for a high probability of a moderate gain. It would appear that most of us are in fact willing to accept small risks of catastrophe: we take planes across the Atlantic instead of going by ship, we drive cars instead of taking trains and we travel instead of staying at home. As a society we balance off saving lives by spending money on road safety measures and medical services against other uses of the resources, and so on indefinitely. Since it is not $a$ priori irrational to accept risks of catastrophe in this way it cannot be said to be a priori irrational for those in the "original position" to be prepared to accept catastrophic outcomes. ${ }^{23}$
\end{abstract}

One can hardly argue with Barry's observation that people are generally willing to take a small risk of catastrophe for a large benefit. Yet one of the stipulations of the original position is that the parties have no knowledge of the relative likelihood of the various outcomes. Barry's counterexamples

121 See MARTIN, supra note 109 , at 102 . It has also been observed that Rawls's later writings make no mention of the maximin rule of decision. See Stephen M. Griffin, Reconstructing Rawls's Theory of Justice: Developing a Public Values Philosophy of the Constitution, 62 N.Y.U. L. REV. 715, 737 (1987) ("[T]he maximin rule for decisions under uncertainty does not appear in [Rawls's] recent articles."). Despite this criticism, the maximin rule of decision continues to enjoy significant acceptance among legal scholars. See, e.g., Jeffrey L. Harrison, A Case for Loss Sharing, 56 S. CAL. L. REV. 573, 598 (1983) ("In the case of contract losses ... maximin is likely to be an attractive decisionmaking rule.").

122 See, e.g., DAVID LEWIS SCHAEFER, JUSTICE OR TYRANNY?: A CRITIQUE OF JOHN RAWLS' THEORY OF JUSTICE 34 (1979) ("Rawls's own preference for the maximin rule appears to represent nothing more than a personal timidity."); Alan Schwartz, Proposals for Products Liability Reform: A Theoretical Synthesis, 97 YALE L.J. 353, 359 (1988) (arguing that maximin is most attractive to the risk averse, but that most people are not risk averse in the context of products liability law because they "know that the worst outcome ... is substantially mitigated by existing social safety nets").

123 BRIAN BARRY, THE LIBERAL THEORY OF JUSTICE 107 (1973). 
seem inappropriate and misguided in light of this stipulation. ${ }^{124}$ We do take planes across the ocean, but only because we know that airplane crashes are quite rare in comparison to total passenger miles flown. One wonders how many would have volunteered for the first transatlantic test flight. The parties in the original position might well select some form of utilitarianism if they could be assured that they almost certainly would not end up among society's worst-off. In the absence of any such assurance, however, the situation is quite different.

There remains the related criticism that some real people are far greater risk-takers than maximin admits. What about people who gamble regularly, for instance? How can it be said that they adhere to worst-case analysis? Although I will make no attempt here to canvass a vast literature on game and decision theory as applied to gambling, I will say that this criticism strikes me as wrong-headed. First, it again ignores the fact that regular gamblers are not ignorant as to the relative likelihoods of possible outcomes. Roulette players know the odds against picking a particular number, a particular color, and particular combinations. Horseplayers have extensive past performance records with which to judge probable future finishes. Second, the criticism overstates individual differences in risk attitude. Granted, some of us are far more risk-averse than others. Yet we all gamble on some things (how many Americans regularly exceed the speed limit?), and virtually none of us will gamble on other things (how many of us will switch to the other side of the highway when traffic in our direction is bumper-to-bumper?). In other words, we are all gamblers, but even the most robust risk-takers learn to pick their spots. Most horseplayers do not simply put money on the longest shot in every race. Many will only play favorites. Some make a habit of playing long shots, but even they will seek out the longest shot with what they consider to be a realistic chance of finishing in the money. There are those who can be found spending last month's rent money on lottery tickets, but these people prove only that gambling can become an addiction, not that maximin is a false description of how people will behave. A pathological compulsion to gamble no more reflects a favorable "attitude toward risk" than a pathological compulsion to steal reflects a favorable "attitude toward crime." Putting compulsive gamblers to one side, I do not believe that even the most aggressive risk-takers would gamble with the basic structure of the court system by which their

${ }^{124}$ For a global, and rather harsh, critique of Barry's effort, see Edward F. McClennen, Review: Brian Barry, The Liberal Theory of Justice, 3 SOC. THEORY \& PRAC. 117, 118 (1974), which criticizes Barry's "criticism of the claim that persons behind the veil of ignorance will, if they are rational, choose a maximin policy." 
liberties (including the freedom to gamble!) will be protected. They will figure that there are better places to take their risks.

Another criticism of maximin is that it irrationally ignores best-case scenarios. ${ }^{125}$ Again suppose that the worst-case scenario under option 1 is negative 7 and that the worst-case scenario under option 3 is positive 5 . This time, however, further suppose that the best-case scenario under option 3 is only positive 8 , and the best-case scenario under option 1 is positive 20 . (Of course, we still lack any knowledge as to relative probability of outcomes.) Is it still rational to select option 3 on the ground that it maximizes the minimum outcome? Wouldn't it now be equally rational to shoot the moon with option 1 ?

If the values in the hypothetical represented fungible primary goods that could be saved or consumed in an unrestricted manner, the decisions would be equally rational. The choice would indeed depend on one's attitude toward risk. But suppose that the values represented some perishable good that for some reason could not be alienated. Suppose the numbers represented cartons of milk, and the decision maker was alone in a remote geographical location with no way to deliver the milk to market. Surely the rational decision maker would choose option 3 over option 1 because gaining five cartons of milk is better than giving up seven cartons, and because (under the peculiar circumstances) gaining twenty cartons is no better than gaining eight cartons; most of the twenty cartons would spoil before they could be consumed. This is an example of Rawls's second factor for the applicability of maximin - that the person choosing cares very little about what might be gained above the minimum stipend that could be guaranteed by following the maximin rule. In other words, the criticism that maximin irrationally ignores best-case scenarios is overstated. In situations where improvement on a best-case scenario would represent nothing more than gravy, it is perfectly rational to exclude best-case scenarios from further consideration.

Still another criticism of Rawls's use of the maximin rule of decision is that it ignores other equally or more rational strategies under conditions of uncertainty. ${ }^{126}$ One suggested rival to maximin is the principle of insuffi-

125 See, e.g., Lawrence Solum \& Stephen Marzen, Truth and Uncertainty: Legal Control of the Destruction of Evidence, 36 EMORY L.J. 1085, 1159 (1987) ("The problem with the maximin rule is that it seems difficult to provide a rational justification for the pessimism implicit in the rule.").

${ }_{126}$ See, e.g., David Kaye, Playing Games with Justice: Rawls and the Maximin Rule, 6 SOC. THEORY \& PRAC. 33, 37 (1980) ("Given these features of the original position, then, our only recourse is to appeal to one of the methods of decision making-under uncertainty. But why the maximin rule? The maximax rule, the pessimism-optimism rule, the equiprobability rule, and the minimax regret rule are also consistent with rationality and complete igno- 
cient reason. The principle of insufficient reason simply holds that, where the relative likelihoods of outcomes are unknown, the decision maker should assume that all outcomes are equally likely. ${ }^{127}$ Thus, if option 1 has a worst-case of negative 7 and a best-case of positive 25 , and option 2 has a worst-case of positive 5 and a best-case of positive 8, the principle of insufficient reason would lead us to choose option 1 . We would assume an equal chance of worst- and best-case outcomes; and because the total value of option I's outcomes (divided by two) equals positive 9, and the total value of option 2's outcomes (divided by two) equals only positive 6.5 , we would conclude that option 1 is superior.

Another rival decision theory is the minimax regret criterion. It focuses on the biggest disparity between parallel outcomes. ${ }^{128}$ Worst-case outcomes are parallel to one another, as are best-case outcomes, and so on. Regret is defined as the deficit between the outcome of the chosen option and the most favorable parallel outcome. Assume option 1 has a worst-case outcome of negative 7, a middle-case outcome of zero, and a best-case outcome of positive 25. Assume option 2 has a worst-case outcome of positive 5 , a middle-case outcome of positive 6 , and a best-case outcome of positive 8 . The maximin rule of decision would lead the decision maker to choose option 2 because positive 5 is better than negative 7. The principle of insufficient reason would give the decision maker a slight preference for option 2 because the total value of outcomes under option 2 exceeds the total value of outcomes under option 1 . The minimax regret criterion, however, would direct the decision maker to select option 1 in order to minimize possible regret. If the decision maker chose option 1 and the worst-case outcome resulted, the amount of regret would be 12 , representing the difference between the actual outcome (negative 7) and the outcome that would have resulted had the other option been chosen. If the decision maker chose option 2 and the best-case outcome occurred, the amount of regret would be 17 (the difference between 25 and 8 ). Because 17 is greater than 12 , regret will be minimized by choosing option 1 .

rance."); cf. David Wood, Rawls's Maximin Argument, 60 PersonAlist 221, 221 (1979) ("This paper considers the question of whether parties in Rawls's original position would choose his two principles of justice ... though there are other principles on the shortlist available to the parties.....").

127 This principle is also known as the Bayles, or LaPlace, criterion. See Craig K. Ihara, Maximin and Other Decision Principles, 12 PHIL. ToPICs 59, 63 (1981) ("The "principal of insufficient reason,' otherwise known as the Bayles, or LaPlace, criterion, states that if we have absolutely no information about the relative probabilities we must assign equal probabilities to alternatives and then adopt the course of action whose expected utility is the highest." (citation omitted)).

${ }^{128}$ See id. at 61-63 (explaining the minimax regret criterion and its relationship to the maximin principle). 
I will not venture to say here whether the maximin rule, the principle of insufficient reason, or the minimax regret criterion is universally the "most rational" under conditions of uncertainty. ${ }^{129}$ Given the particular circumstances of the choice between a system with a guaranteed national forum and a system with no guaranteed national forum, I believe all three modes of decisionmaking point to the same result. At worst, the principle of insufficient reason and the minimax regret criterion would be indeterminate as applied to the choice faced by the hypothetical parties in our "original position." The maximin rule, however, would make a determinate choice in favor of a system with a guaranteed national forum. Therefore, for present purposes, it does not matter whether the principle of insufficient reason or the minimax regret criterion are equally or more rational than the maximin rule of decision. Even if we were to establish a priority in favor of the principle of insufficient reason and the minimax regret criterion, the hypothetical parties would still choose the guaranteed national forum, or they eventually would refer back to maximin as a tiebreaker, as explained below.

The following discussion involves jumping ahead to the topic of the next Part, regarding which choice the parties would make. ${ }^{130}$ Because the argument will be more fully presented in the next Part, I ask the reader to regard some of my numbers as provisionally correct. Assume that the values in the following table represent the protection of individual rights against government overreaching. Let $\mathrm{C} 1$ equal the worst-case scenario, $\mathrm{C} 2$ the middle-case scenario, and C3 the best-case scenario. The two options consist of a system with a guaranteed national forum ${ }^{131}$ and a system with no guaranteed national forum.

\begin{tabular}{|l||c|c|c|}
\hline \multirow{2}{*}{\multicolumn{1}{|c||}{ Options }} & \multicolumn{3}{c|}{ Outcomes } \\
\cline { 2 - 4 } & $\mathrm{C} 1$ & $\mathrm{C} 2$ & $\mathrm{C} 3$ \\
\hline \hline Guaranteed & -5 & 0 & 10 \\
\hline Non-guaranteed & -10 & 0 & 10 \\
\hline
\end{tabular}

The rationale for assigning the worst-case numbers $(\mathrm{C} 1)$ rests on the assumption that nationalization of legal norms will tend to suppress divergences from the median. If the level of individual rights in a national sys-

129 For an argument in favor of the superior rationality of maximizing average utility by way of the principle of insufficient reason, see Wood, supra note 126, at 224.

130 See infra notes 134-36 and accompanying text (explaining why parties in the original position would choose the system with the guaranteed national forum).

${ }^{131}$ In a system with a "guaranteed national forum," the litigant is given the option of asserting the national claim in a national forum, but is not required to do so. 
tem were plotted on a bell curve, the curve would be quite high in the center and would fall off quickly and steeply at both sides. In a decentralized regime, the curve would reach a modest apex, gradually sloping on both sides, and we would expect extremes at both ends of the curve that would not exist under a centralized system. Hence, the table above shows a worse worstcase scenario under a decentralized system.

We would also expect a decentralized system to have a better best-case scenario than a unitary, nationalized system. The same factor that suppresses downward divergences from the median in a nationalized system will also suppress upward divergences in that system. But the choice in our original position is not between a unitary, nationalized system and a decentralized, dual system. The choice is between a dual system with a guaranteed national forum and a dual system with no guarantee of a national forum. From the perspective of the worst-off, the system with a guaranteed national forum offers the best of both worlds.

How can this be? Let us first examine the possible outcomes in a system with no guaranteed national forum. The best-case scenario is that one will end up in a province that protects individual rights to a greater degree than the national minimum. Here it does not matter whether the rightholder can get access to a national forum, for she would not do better there in any event. The worst-case scenario is that one will end up in a province that protects individual rights to a lesser degree than the national minimum. Here it would benefit the rightholder to opt for a national forum because it would bring her up to the national minimum. It being a worst-case scenario, however, we must assume she would be denied the national forum and would have to settle for the nonenforcement or under-enforcement of her national right. Simply stated, a system with no guarantee of a national forum would produce more extreme divergences from the median than a system with a guaranteed national forum.

In a system with a guaranteed national forum, the worst-case scenario would again be to end up in a province that protects individual rights to a lesser degree than the national minimum. But because the rightholder is guaranteed access to a national forum, the outcome is better than in a system where we must assume access would be denied. The best-case scenario is that one ends up in a province that protects individual rights to a greater degree than the national minimum. In this situation, it does not matter that the rightholder has access to a national forum, because she would opt to stay in the provincial court system. Therefore, the best-case outcome in the system with guaranteed access to a national forum is the same as in the system with no guarantee of a national forum. If the litigant were confined to either a national forum or a provincial forum, with no choice between the two, the 
result would be different. In that case, the best-case outcome in the national forum would be worse than the best-case outcome in the provincial forum. But because "guaranteed national forum" denotes giving national claimants an option to litigate in either forum, the best-case outcomes for both systems are equal.

Applying the principle of insufficient reason to this table also produces a victory for the system with guaranteed access to a national forum. The total outcomes for the system with a guaranteed national forum (positive 5) exceed the total outcomes for the system without guaranteed national forum (zero). The same reasoning applies to the minimax regret criterion. The only scenario in which any regret would be suffered is the worst-case scenario, and the regret would be suffered by those choosing the system with no guaranteed national forum.

Some may argue that the number I have assigned to the best-case scenario under the system with a guaranteed national forum is unrealistic. The objection would be that, in practice, rightholders will not always know when it would be in their best interest to opt for the national forum. As a result, their lawyers might develop the habit of opting for a national forum in every case, which would prevent the rightholders from deriving the benefit of living in a province that in fact protects individual rights to a greater degree than the national minimum. Assuming arguendo that this scenario were to develop, at most it would make the principle of insufficient reason and the minimax regret criterion indeterminate. It would not cause those decision strategies to favor the system without a guaranteed national forum. The number in the $\mathrm{C} 3$ column for the system with a guaranteed national forum would never fall below positive 5 . There is absolutely no reason to believe that the worst-case scenario in a nationalized system would be farther from the median than the best-case scenario. If the number for the system with a guaranteed national forum in column $\mathrm{C} 1$ were negative 5 , then the lowest number we could place in column $\mathrm{C} 3$ would be positive 5 . If the lowest number in $\mathrm{Cl}$ were changed to, for example, negative 7 , then the lowest number in $\mathrm{C} 3$ would be positive 7, and so on. C3 would never be closer to the median than $\mathrm{C}$; and, as long as that holds true, neither the principle of insufficient reason nor the minimax regret criterion could ever decisively favor the system without a guaranteed national forum. At most, they would be indecisive, in which case the maximin rule of decision would become the tiebreaker.

There will be at least two objections to my assertion that maximin is superior to the alternatives in this situation. One objection is that I have ignored an alternative that would plainly lead to the exact opposite result of maximin-the maximax rule. This rule "calls for the player always to 
choose that gamble whose first prize is highest, no matter what the dangers in the relative values of the other prizes and penalties." 132 Obviously, the maximax rule would require the decision maker to select the dual system over the unitary system because the dual system's best-case scenario is superior to the unitary system's best-case scenario. But it is difficult to take the maximax rule seriously in any environment other than a game environment. ${ }^{133}$ In a football game, if Michigan trails Notre Dame by six points with one second left in the game, the Michigan quarterback should follow the maximax rule of decision. He must score a touchdown or his team will lose the game. He should not worry about an interception or an incompletion; he should call a play exclusively with a best-case scenario in mind because he is indifferent to the degree of any resulting failure. Outside of a game environment, however, maximax has little application, and certainly is inappropriate for selecting a court structure aimed at protecting individual rights. We care a great deal about the precise degree to which the court system fails to protect our individual rights.

The second potential objection is that I have manipulated the values in the table to make the insufficient reason and minimax regret criteria indeterminate. If the middle- or best-case scenarios under the dual system were even slightly better, the principle of insufficient reason would be decisively in favor of the nonguaranteed national forum system. If the best-case scenario under the dual system was just slightly better, or if the best-case scenario under the unitary system was just slightly worse, the minimax regret criterion would be decisively in favor of the nonguaranteed national forum system. The response to this objection, of course, involves the subject of the next Part. The preliminary answer, however, is simply that there is no good reason to believe that a system without a guaranteed national forum has more upside potential than downside potential. Nor is there any particular reason to believe that the difference between the upside potential of a nonguaranteed system and the upside potential of a guaranteed system exceeds the difference between the downside potential of each. The only prediction in which we can have a high degree of confidence is that the nonguaranteed system has both a higher upside potential and a lower downside potential than the guaranteed system.

The remaining issue regarding maximin is the manner in which it is to be applied to the choice between court systems. Under the maximin rule of

132 WILLIAM J. BAUMOL, ECONOMIC THEORY AND OPERATIONS ANALYSIS 461 (4th ed. 1977).

${ }^{133}$ See id. (suggesting that the maximax criterion "does not seem to have been put forth seriously anywhere in the literature," and "is a decision rule well suited to the temperament of a plunger'). 
decision, the relevant question for the parties is not which court system offers the least-harmful worst-case scenario for society as a whole. Instead, the relevant question is which court system offers the least-harmful worstcase scenario for each party as an individual. If the parties perceive a conflict of interest, they are permitted to opt in favor of their perceived selfinterest. If, for example, the parties believe that a system with no guaranteed national forum would present the least-harmful worst-case scenario for society, but believe that a system with a guaranteed national forum would offer the least-harmful worst-case scenario for themselves as individuals, they are free to choose the guaranteed system. This freedom, of course, does not stem from the nature of maximin. It stems from the purpose of the original position, which is to ascertain where individual self-interest takes us when shorn of information that would lead us to partisanship or interestgroup maneuvering. It is a common misinterpretation of the original position that the parties are supposed to transcend self-interest. The veil of ignorance does not prevent the parties from acting in their self-interest; it simply forces them to take a generic view of what is in the interest of individual citizens. Rawls clearly did not foresee the parties exercising choices out of altruism. After all, if people were angels, there would be no need for a concept of justice (and certainly no need for courts!). The thought experiment Rawls described was one in which free and equal individuals, acting rationally in their self-interest, but kept away from partisanship, were to select principles by which to judge societal institutions.

The parties in our original position, then, are required to choose the court system that presents the least-harmful worst-case scenario for them as individuals. The veil of ignorance deprives them of knowledge about their personal characteristics. The combination of these two conditions forces the parties to view things from the perspective of the least well-off in society; the parties must ask, "if one were about to enter a society as one of the least well-off, what type of court system would one prefer?" Thus, in the table described above, the worst-case scenarios represent worst cases for individuals, not for society as a whole.

By what measure are the parties to judge who is among the "least welloff' in society? Individuals have varying ideas about who is worse off than whom; yet, the veil of ignorance prevents the parties from knowing their personal conceptions of the good. As with other matters of self-interest, the parties are to view "least well-off" generically. Because the purpose of the present thought experiment is to select a court system for a constitutional democracy, "least well-off' should be viewed from the standpoint of individual rights. In other words, the least well-off in society are those who are most vulnerable to the deprivation of their individual constitutional rights. 
By applying general principles of politics and sociology, we can expect the most vulnerable to be (1) poor and (2) set off from the dominant population in some way that makes them targets for organized persecution and oppression. It is unimportant to specify exactly how poor is poor, just as it is unimportant to decide exactly which groups are targets for oppression. It is enough for the parties to know that they are supposed to choose between the federal forum norm and the state court primacy norm on the basis of which would present the least-harmful worst-case scenario for a poor person who belongs to some group that is a target of organized persecution and oppression. The parties must adopt this viewpoint because, under conditions of uncertainty about likelihoods, they must assume that they will be entering the society as one of the least well-off.

\section{CHOOSING A FoRUM ALLOCATION RULE}

As an academic exercise, it would be most intriguing to give the parties in the original position an infinite number of choices. They could be given the options of a nationwide court system with centralized control over norms, or of a multi-layered system with diffuse control over norms. They could also be presented with more radical alternatives, such as a single set of autonomous provincial or local tribunals subject to no central authority whatsoever. A still more utopian possibility would be a legal system with no "courts" at all, only local mediators and go-betweens who resolve nascent conflicts by consensus-building. It would be a fascinating thought experiment, one well worth the trouble. It would, however, be beyond the scope of this Article. My point of departure is the ongoing conceptual and doctrinal struggle between the ideal of a judicial system whose outlying courts are more-or-less satellite tribunals and the ideal of a judicial system whose outlying courts are more-or-less sovereign. No contemporary American legal scholar has seriously suggested adopting a judicial system lacking a central tribunal, let alone a legal system completely lacking coercive powers. It is not that these more radical alternatives (and others) are unimaginable, but rather that they fall beyond the conceptual boundaries of the present debate about the allocation of constitutional claims between federal and state courts.

The parties in our version of the original position, then, are artificially limited to a choice between a system in which claims arising under national law are generally guaranteed a national forum and a system in which most national claims are fully and finally adjudicated in provincial courts. They labor under a veil of ignorance where they know nothing about their personal characteristics and nothing about the actual history of the United States in general or federalism in particular. They do know that they are to 
choose a forum allocation rule for a constitutional democracy, but they do not know the precise content of its constitution. They must choose the forum allocation rule that offers the least-harmful worst-case scenario for the least well-off in society.

One might think that what Erwin Chemerinsky calls the litigant choice principle ${ }^{134}$ would be chosen in the original position. Under this norm, litigants would always have the option to adjudicate their claims in either court system. The litigant choice principle would not be chosen, however, because the least-well-off in society would be worried that their opponents in litigation would have their own constitutional rights. If their opponents had their own constitutional rights, their choice of forum might trump the leastwell-off person's choice of forum. The least-well-off person's suspicion will be that rich people, or members of the dominant group, will somehow have their interests classified as "constitutional rights."

Even assuming, arguendo, that the litigant choice principle would be chosen in the original position, it would be radically unstable, and thereby impermissible. The national government would not be able to sustain initiatives on behalf of the common good as long as the interests of the nation as a whole and the individual province were inimical to one another. Provincial courts would constantly undermine the programs of the national government whenever those programs sought to overcome interprovincial collective action problems.

For example, assume that the national government determined that a certain narcotic was doing irreparable harm to the national population. The national legislature then enacted a statute criminalizing the production or transportation of that drug. Further assume that the production and exportation of this drug constituted a large portion of one province's annual gross product. Loss of the sales and tax receipts stemming from the drug's production would ruin the province's economy. Under a regime of litigant choice, few would ever be punished for drug sales. Producers and exporters who were prosecuted in national tribunals could always remove to provincial courts, which are sure to be protective of the province's economic livelihood.

A society whose government is incapable of overcoming collective action problems through appropriate interventions-including use of the criminal law-simply will not last. All but the most extreme libertarians will agree that one of the essential roles of government is to tackle problems that the market or voluntary individual action is incapable of solving. On

${ }^{134}$ See Erwin Chemerinsky, Parity Reconsidered: Defining a Role for the Federal Judiciary, 36 UCLA L. REV. 233, 300 (1988) (explaining that the litigant choice principle allows individuals with constitutional claims to choose between litigating in federal or state court). 
reflection, then, the litigant choice principle must be scratched from the menu. ${ }^{135}$

Only two options remain: (1) the system in which national claims are generally guaranteed a national forum, and (2) the system where national claims are generally litigated to conclusion in provincial courts. The parties in our original position would choose the system with a guaranteed national forum over the system without. To see why, refer to the table introduced in the previous section:

\begin{tabular}{|l||c|c|c|}
\hline \multirow{2}{*}{\multicolumn{1}{|c||}{ Options }} & \multicolumn{3}{c|}{ Outcomes } \\
\cline { 2 - 4 } & $\mathrm{C} 1$ & $\mathrm{C} 2$ & $\mathrm{C} 3$ \\
\hline \hline Guaranteed & -5 & 0 & 10 \\
\hline Non-guaranteed & -10 & 0 & 10 \\
\hline
\end{tabular}

As explained above, given the values in this table, all three rules of decision require the parties to select the system with a guaranteed national forum. Even if one concedes that the value for $\mathrm{C} 3$ in the guaranteed column ought to be positive 5 rather than positive 10, the maximin rule of decision would still require the parties to select the guaranteed system. The principles of insufficient reason and minimax regret criterion would then both be indecisive.

What remains, of course, is to justify the placement of these particular values in the table. The justification must explain two features of the table: (1) why the best outcome under the nonguaranteed system is no better than the worst outcome is bad, and (2) why the difference between the values in C3 is no greater than, and indeed is not even as great as, the difference be-

135 There is an issue here as to whether stability ought to be considered at this relatively lofty level of abstraction. Christopher Wonnell has criticized Rawls's discussion of stability for its failure to distinguish between pure normative philosophy and applied political philosophy. See Christopher T. Wonnell, Problems in the Application of Political Philosophy to Law, 86 MiCH. L. REV. 123, 144-47 (1987) (arguing that "Rawls' emphasis upon the stability of his conception" illustrates his confusion about the distinct functions of pure normative philosophy and applied political philosophy). According to Wonnell, pure normative political philosophy concerns itself only with what justifies particular legal rules or political actions. See id. at 125 (defining Wonnell's perception of "pure normative philosophy"). It does not concem itself with whether or not real individuals are likely to behave in accordance with the philosophy. See id. at 126-28 (distinguishing pure normative philosophy from applied normative philosophy, which is concerned with how political philosophy affects individual actions). The latter concern is the domain of applied political philosophy. Although Wonnell's taxonomy is valuable as a heuristic device, I doubt whether keeping these two types of philosophies distinct is as important as simply confining oneself to a single level of abstraction at a time. 
tween the values in $\mathrm{Cl}$. If the best outcome under the nonguaranteed system were higher than 10 (and if the worst outcome remained negative 10), then the principle of insufficient reason would prefer the nonguaranteed system. If the difference between the best outcomes were greater than 5 , and if the rest of the table remained unchanged, then the minimax regret criterion would prefer the nonguaranteed system.

The explanation for both features is the same: the relative lack of intraprovincial diversity that creates a higher upside potential for the nonguaranteed system creates a lower downside potential to the same degree. What allows a relatively small and insular society to have a higher level of individual freedoms is the relative homogeneity of customs, values, and interests among the population. For example, in a tribal society where religious ceremonies involving animal sacrifice date back to time immemorial, the freedom to kill animals is far more likely to be protected than in a diverse society that also includes groups who abhor ritual killing of any kind. Cultural and religious homogeneity within the tribe will see to the vigilant protection of a freedom that might wither under the attack of cultural and religious outsiders who have a say in society-wide norms. To take an actual example from contemporary America, the freedom to smoke cigarettes is more likely to be protected in North Carolina than in the nation as a whole. The relatively homogenous interest in the survival of the tobacco industry in North Carolina ensures this freedom. But homogeneity is a double-edged sword. In a tribal society, where the marriage ritual of bridal capture and forced consummation dates back to time immemorial, women's freedom to control their own bodies is far less likely to be protected than in a society that abhors rape. To take a contemporary example from the United States, if Roe $v$. Wade ${ }^{136}$ were overruled today, a woman's right to terminate her pregnancy would be far shakier in Pennsylvania or Massachusetts-states with large Catholic populations - than in California or Hawaii. Breaking a heterogeneous population into smaller homogenous populations is not unlike playing the stock market on a margin account. By borrowing money, the investor increases her leverage, and any gain is magnified. But any loss will be magnified, too, and to the exact same degree.

With the determination in favor of the guaranteed system, the affirmative case for the federal forum norm is complete. Free and equal persons in a non-partisan initial situation would select this court structure for their generic constitutional democracy because they would view it to be in their self-interest, as broadly conceived. This determination signifies that political philosophy lends support to the federal forum norm. It signifies that the

136410 U.S. 113 (1973). 
federal forum norm has value in a liberal constitutional state. It does not tell us how much value the norm has, but it at least instructs us not to ignore it or summarily label it as normatively unattractive.

\section{CONCLUSION}

In this Article, I have taken on two analytically dissimilar projects. In one, I specifically targeted the received wisdom in federal courts law, which is that the Supreme Court should take affirmative measures to build up the competence of state court constitutional adjudication. This wisdom has generated several doctrines that divert federal constitutional claims from federal courts to state courts, in part for the purpose of acculturating state judges into the national community of constitutional values. I concluded that this program runs afoul of a fundamental premise of American political and legal culture-namely, that government generally may not sacrifice individual rights for the collective good.

The other analytical project rested on the same individualist premise but had a different purpose. I argued that, whether or not the received wisdom is attractive, it has a normatively formidable rival-the federal forum norm. I attempted to demonstrate the federal forum norm's appeal by constructing a thought experiment. Would rational people, blinded to their own demographic characteristics, choose to live in a society where the court system generally guarantees national constitutional claimants one plenary hearing in a national tribunal, or in a society where most constitutional claims are finally determined in a local tribunal? I concluded that a rational person would choose the first system. Abstract rationality, from an individual standpoint, favors a federal forum norm over the state court primacy norm.

Political philosophy, of course, is no substitute for legal, historical, or mid-level policy analysis. Philosophy is an appropriate supplement to those modes of analysis. Whether or not the Supreme Court cares to admit it, political philosophy has played important justificatory and rhetorical roles in its forum allocation jurisprudence. No one should fault the Court for employing political philosophy as part of its decisionmaking apparatus. But the job of an academic is to shed light on that process, to test it against society's most fundamental normative commitments, and, if that process is found wanting, to suggest a more fruitful direction. Although it has produced some disjointedness, I have tried to do that job here. 